\title{
Conventional Methods and Emerging Wastewater Polishing Technologies for Palm Oil Mill Effluent Treatment: A Review
}

Wai Loan Liew ${ }^{1}$, Mohd. Azraai Kassim ${ }^{1} *$ Khalida Muda ${ }^{1,3}$, Soh Kheang Loh $^{2}$, Augustine Chioma Affam ${ }^{3}$

${ }^{1}$ Water Research Alliance, Level 2, Block C07, Faculty of Civil Engineering, Universiti Teknologi Malaysia, 81310 Skudai, Johor, Malaysia

${ }^{2}$ Malaysian Palm Oil Board, P.O. Box 10620, 50720 Kuala Lumpur, Malaysia

${ }^{3}$ Faculty of Civil Engineering, Department of Environmental Engineering, Universiti Teknologi Malaysia, 81310 Skudai, Johor, Malaysia

Corresponding Author: azraai@utm.my Tel: +6(07)553 0244, Fax: +6(07)557 1700

\begin{abstract}
The Malaysian palm oil industry is a major revenue earner and the country is ranked as one of the largest producers in the world. However, growth of the industry is synonymous with a massive production of agro-industrial wastewater. As an environmental protection and public health concern, the highly polluting palm oil mill effluent (POME) has become a major attention-grabber. Hence, the industry is targeting for POME pollution abatement in order to promote a greener image of palm oil and to achieve sustainability. At present, most palm oil mills have adopted the ponding system for treatment. Due to the successful POME pollution abatement experiences, Malaysia is currently planning to revise the effluent quality standards towards a more stringent discharge limits. Hence, the current trend of POME research focuses on developing tertiary treatment or polishing systems for better effluent management. Biotechnologically-advanced POME tertiary (polishing) technologies as well as other physicochemical methods are gaining much attention as these processes are the key players to push the industry towards the goal of environmental sustainability. There are still ongoing treatment technologies being researched and the
\end{abstract}


outcomes maybe available in a while. However, the research completed so far are compiled herein and reported for the first time to acquire a better perspective and insight on the subject with a view of meeting the new standards. To this end, the most feasible technology could be the combination of advanced biological processes (bioreactor systems) with extended aeration, followed by solids separation prior to discharge. Chemical dosing is favoured only if effluent of higher quality is anticipated.

Keywords: palm oil, palm oil mill effluent, polishing technologies, sustainability, tertiary treatment

\section{INTRODUCTION}

The palm oil industry has been an important economic contributor for countries like Malaysia, Thailand, Indonesia, Colombia and other tropical developing regions. While impressive export and production figures are widely reported in almost all palm oil or POME treatment literature, it is not astonishing that a massive production of the effluent has turned out to be a main source of water pollution. In Malaysia, it is estimated that at least 60 million tonnes of POME was generated in the year 2009 alone ( $\mathrm{Ng}$ et al., 2011). For each tonne of fresh fruit bunch (FFB) processed, large quantities of POME containing $29-33 \mathrm{~kg}$ of $30^{\circ} \mathrm{C}$, 3-days Biochemical Oxygen Demand $\left(\mathrm{BOD}_{3}\right)$ are discharged into the water bodies (Thanh et al., 1980).

In Malaysia, a lot of efforts on research and development had made the industry dotted with significant successful pollution abatement history. Being the pioneer in targeting sustainable palm oil industry, Malaysia has gained valuable experiences in developing technologies for both upstream and downstream processing. In the year 2011, the palm oil processing mills 
attained $95.5 \%$ compliance to the effluent discharge limits (DOE, 2011). This achievement will continue to soar higher when further aim for the implementation of greater environmental management initiatives such as Cleaner Production (CP), biogas capture for Clean Development Mechanism (CDM) (PEMANDU, 2010; Ng et al., 2011), Roundtable for Sustainable Palm Oil (RSPO) (Basiron, 2007), and possibly towards zero discharge is made.

Previous reviews have been published emphasizing the current conventional POME treatment methods and state-of-the-art laboratory treatability studies. Some papers emphasize reusing the effluent and the industry's solid wastes to attempt resource recovery. As the current scenario in palm oil research focus on tertiary/polishing treatment of POME to progress towards the challenging $20 \mathrm{mg} \mathrm{L}^{-1} \mathrm{BOD}_{3}$ discharge limit, this paper aims to concisely review and report the POME tertiary/polishing technologies which have not been compiled before so as to gain an insight for better effluent management.

\subsection{The palm oil industry at a glance}

Development of the oil palm sector is marked as an industrial success story. As the main plantation commodity in Malaysia, the total plantation area has expanded from a mere 400 hectares planted area (year 1920) to 54,000 hectares (year 1960); subsequently to 2,692,286 hectares (year 1996) and the most recent statistic at year 2011 reviewed is 5,000,109 hectares of oil palm planted area (DOE, 1999; MPOB, 2012). Travelling across the country, oil palm trees are seen nearly in every bit of unfilled land. According to a stature report by Basiron (2007), forest and oil palm recorded 61.82 and $13.20 \%$, respectively for land coverage in Malaysia. From such a huge area of palm oil plantation, the country is capable of producing more than 92 million tonnes of FFB to be processed by palm oil mills which are spread across the nation (MPOB, 2012). Up to year 2011, Malaysia recorded a total of 426 palm oil 
mills in operation (DOE, 2011; MPOB, 2012), with 250 mills operated in Peninsular Malaysia and the remaining 176 mills in Sabah and Sarawak.

Fig. 1 illustrates the distribution of the palm oil mills throughout the country. In the Peninsular, Pahang state has the highest number of mills while Sabah state tops the country at 123 mills in operation. Despite having the highest number of palm oil processing mills, Sabah state nevertheless is well-known for its biodiversity lushness. Major rivers in Sabah state like the Kinabatangan River, the Segaliud River, the Muanad River, the Segama River, the Pang Burong River, and the Kalumpang River are important to the local communities, tourism activities, and are getting severe exertions on conservation. Hence, most environmental concerns allied with the palm oil industry accentuates in the Sabah state, such as the implementation of the $20 \mathrm{mg} \mathrm{L}^{-1} \mathrm{BOD}_{3}$ discharge limit. Seeing the abundant number of palm oil processing mills in Malaysia, 30 additional mills are indeed under planning and construction throughout the country while 3 existing mills are not in operation (MPOB, 2012). With data on the amount of FFB processed by mills, the quantity of POME production can be projected. In Malaysia, the recorded national production rate for POME is 0.67 cubic meters per tonne of FFB processed by mills (DOE, 1999; Ma, 1999; Ng et al., 2011). POME can be further divided into the sterilizer condensate, clarification wastewater, and hydrocyclone wastewater in a ratio of 9:15:1 (Wu et al., 2010). The information in Fig. 1 shows the booming Malaysian palm oil industry (year 2011), but in contrast, a large amount of liquid wastes are produced requiring appropriate treatment before discharge.

(Figure 1 goes approximately here.)

Fig. 1 - An overview of the Malaysian palm oil industry in year 2011. A - the number of palm oil processing mills in operation; B - the fresh fruit bunches processed by mills 
(tonnes); $\mathrm{C}$ - the estimated POME production (tonnes); D - sterilizer condensate (tonnes); $\mathrm{E}$ - clarification wastewater (tonnes); F - hydrocyclone wastewater (tonnes).

\subsection{Palm oil factory processes as sources of pollution}

In Malaysia, the wet palm oil milling process is typically applied. The method uses hot water to leach out the oil, which also explains the large consumption of water resources for milling processes and the concomitant large production of wastewater. A less popular dry milling method uses mechanical presses on the digested mash to squeeze out the crude oil. In short, the crude palm oil extraction process starts with collection of the FFB from the oil palm plantations. In the palm oil processing mills, fresh bunches are delivered into horizontal sterilizers (commonly used in modern factories compared to the vertical sterilizers) or pressure vessels where a live steam is applied against the fruits at approximately $100-140^{\circ} \mathrm{C}$ for 25-30 minutes (small bunches, 3-6 kg) or 50-75 minutes (larger bunches, $17 \mathrm{~kg}$ ) to cook the palm fruits. The reported pressure used in sterilizers was 35-45 psi. The primary objective of sterilizing the fresh bunches is to deactivate and henceforth inhibit the enzyme activity (lipolytic enzymes) of palm fruits. The fat-splitting or lypolitic enzymes can result in the breaking down of oil into free fatty acids (FFA). A rise in FFA could lead to low oil yield as the fat-splitting enzymes would hydrolyse much of the oil during the fruit pulping process. Other motives of sterilization include preparation of fruit pericarp for subsequent processing and pre-conditioning the nuts to lessen kernel breakage during both pressing and nut cracking. Moreover, sterilization helps to smoothen the latter process of mechanical stripping/threshing to free the palm fruits from the bunches. Mechanical stripping is facilitated when sufficient moist heat in the form of steam during sterilization can penetrate to the points of attachment between the fruits and bunches, hence allowing hydrolysis at these points. These sterilized fruits are then subsequently smashed to press out the crude palm oil. 
The oil is further treated in purifiers and vacuum dried for storage and export (Ab Rahman et al., 2011; Thanh et al., 1980; PORIM, 1985).

(Figure 2 goes approximately here.)

Fig. 2 - Typical palm oil milling processes in addition to the sources of water pollution and by-products generation from the processing of one tonne of FFB.

In the process of crude palm oil extraction, huge quantities of water is required and is typically obtained from the adjacent freshwater resources, i.e., the rivers, which incurs very little treatment and pumping costs. A detailed palm oil milling process, describing the sources and quantities of water and its subsequent wastewater generation, as well as the products and by-products alongside the milling processes is presented in Fig. 2. The milling process coupled with the information of water, wastewater, and by-products were results obtained from a survey of seven local palm oil mills. The factories involved are located in different locations around the Johore state, which are Kota Tinggi, Bukit Besar, Penggeli, Paloh, Kahang, Segamat, and one factory in Seri Ulu Langat (Selangor state). To process 1 tonne $(1,000 \mathrm{~kg})$ of $\mathrm{FFB}$, about 1.50 cubic meters of water source are extracted mainly for the operation of boilers and the hydrocyclone separator (DOE, 1999; Ma, 1999; Chavalparit et al., 2006). In Malaysia, all palm oil mills have at least one boiler with steam generation capacity varying between 15,000 to $30,000 \mathrm{Ib}$ per hour. Water-tube (WT) boilers and firetube (FT) boilers are two common types used in local palm oil mills but the WT boilers are favoured due to higher steam generation capacity (Rashid et al., 1998). The natural water is treated and made suitable as boiler feed water to prevent corrosion of the boiler metal, scale formation, foaming, and priming. In the WT boilers, the boiler feed water is evaporated into steam under the influence by steam pressure, steam temperature, steam quality, and feed 
water temperature. At a process throughput level of 60 tonnes FFB per hour, about 410 to 455 $\mathrm{kg}_{\text {tonne }} \mathrm{h}^{-1}$ hour $^{-1}$ of steam is required (Cooper, 1983). The hydrocyclone separators on the other hand use the flow of water to separate two components of different densities by centrifugal force. Palm kernels have lower density compared to the palm shells. Using a large quantity of water, the equipment separates wet kernels for further processing in the kernel silo and wet shells. The wet shells, combining with other palm biomasses (dry shells and fibres) are used as boiler fuels for fuel and electricity generation for the milling processes (Ma et al., 1993). An alternative to the hydrocyclone separator is the more conventional clay bath separator which requires lower power consumption and capital costs (PORIM, 1985; Ab Rahman et al., 2011).

In the milling processes, about $50 \%$ ( 0.75 cubic meters) of the water source eventually became POME while the other $50 \%$ turn out to be used water. The used water is discharged into the drains or rivers without going neither into the effluent stream nor the wastewater treatment system. The generation of POME is illustrated in Fig. 2 and the three main wastewater sources which combine to make up the POME is represented as Source 1 (sterilizer condensate), Source 8 (clarification wastewater), and Source 10 (hydrocyclone wastewater). Typical characteristics of this type of wastewater is shown in Table 1 (DOE, 1999; Khalid and Wan Mustafa, 1992; Ma et al., 1993; Rupani et al., 2010; Wu et al., 2010).

(Table 1 goes approximately here.)

Table 1 - Characteristics of different sources of wastewater combining to produce the POME.

The sterilizer condensate (or sterilizer waste), wastewater Source 1 in Fig. 2 resulted from the FFB sterilization process in a horizontal sterilizer or horizontal cylindrical autoclaves (DOE, 
The largest portion of wastewater contributing to the POME (about 60\%) is the clarification wastewater (or separator sludge) discharged from the process operation of clarification of the extracted crude palm oil, denoted as wastewater Source 8 in Fig. 2. Pulp press is used to extract crude palm oil from the digested palm fruits. However, the crude oil produced at this point is a mixture of palm oil $(35-45 \%)$, water $(45-55 \%)$, and impurities consisting of either soluble or insoluble vegetable matter in varying proportions (DOE, 1999). Through the 
The third wastewater source (no. 10 in Fig. 2) is the hydrocyclone wastewater which makes up around 4\% of the POME (DOE, 1999; Wu et al., 2010). Residue (press cake) from the press machine consists of a mixture of fibre and nuts. While the fibres will be separated and sent to the boiler house, the remaining nuts are sent to the nut cracker and subsequently to the hydrocyclone separator (Lam and Lee, 2011). The process separates the cracked mixture of kernel and empty shell based on their differences in specific gravity. Employing a separation medium of clay suspension or salt solution with a specific gravity of 1.12 , the hydrocyclone can effectively separate the kernels and the shells with specific gravity of 1.07 and $1.15-$ 1.25 respectively (DOE, 1999; PORIM, 1985). The generation rate of hydrocyclone wastewater is 0.03 cubic meters per tonne of FFB processed. 
Other than the three main waste streams, there are minor sources of relatively clean wastewater which constitute the POME. Since the volume is unpredictable and the effect is inconsequential, these wastewater sources are often neglected and very seldom reported. The quantity of this wastewater depends on the palm oil mill operation. A survey of the palm oil mills identified 9 additional sources of wastewater generation, other than the typically reported sterilizer condensate, clarification wastewater, and hydrocyclone wastewater. They are presented in Fig. 2 as wastewater source 2, 3, 4, 5, 6, 7, 9, 11, and 12.

Wastewater Source 2 is generated as a result of floor washing in the digester and pulp press operation site. In the digester, soft and stripped palm fruits were mashed by the central rotating shaft carrying a number of mechanical arms. The high temperature rotating mechanism loosen the fruit's outer covering from nuts before delivering the homogenized oil mash to squeeze out the crude palm oil (Embrandiri et al., 2012; Lam and Lee, 2011). The produced crude palm oil with entrained impurities requires oil separation and purification. This is done in the oil room where clarification of the crude oil occurs. Floor washing in the oil room contributes to wastewater Source 3 (Embrandiri et al., 2012). Also in the oil room, the purification of crude oil produces a minor effluent which is denoted by wastewater Source 4. The purification process is mainly aimed to achieve a high degree of moisture removal (Chungsiriporn et al., 2006; Embrandiri et al., 2012; Prasertsan and Prasertsan, 1996). Vacuum drier further purifies the crude oil until it reaches moisture and dirt content below 0.1 and $0.01 \%$ respectively (DOE, 1999; Embrandiri et al., 2012). The occurrence of water overflowing from the vacuum dryer machineries contributes to wastewater Source 5. 
Purification of crude oil in the horizontal or vertical clarification tank helps in maintaining oxidative stability besides preventing gums deposition (Igwe and Onyegbado, 2007). Besides the procedure of refinement of oil skimmed-off from the top of the clarification tank, the bottom phase processing contributes to some sources of wastewater. In the oil room, the bottom phase which is generally underflow sludge will go through oil recovery. Minor sources of effluent come from the strainer process (wastewater Source 6) and the desander process (wastewater Source 7). Strainer is a pre-treatment process for the underflow sludge whereby the solid bits are removed. The diluted crude oil or sludge is hence treated in desander for the purpose of sand removal prior to feeding into the high speed centrifuge to achieve oil recovery (PORIM, 1985).

Aside the oil room, there are several sources of wastewater generation as denoted by wastewater Sources 11 and 12. While large quantities of water are used in the form of hot steam, the steam turbine is an important section in the palm oil mill for steam (heat) generation as well as electricity as a by-product. Cooling the turbine generates a certain volume of wastewater to be treated in the wastewater treatment system (Chungsiriporn et al., 2006). The boiler too is found to contribute to some wastewater from the steam condensate and boiler blow down. Besides, there are also floor washing in the premise at locations where empty fruit bunches (EFB) are delivered for screw pressing. This is denoted as wastewater Source 9 in Fig. 2.

Due to various sources of wastewater, the resulting POME has fluctuating characteristics. The characterization of POME collected from different batches or days from different mills too will give different analytical results. Moreover, different oil extraction techniques, quality 
of the palm fruits, the factory requirement on effluent discharge limit, climate as well as the condition of the palm oil processing are thinkable reasons for the dissimilarity. Different cropping season of the oil palm and mill activities have also affected the quantity and quality of the POME produced (Wu et al., 2010).

The waste streams from the hot water and steam usually delivers sterilized condensate, and the clarification wastewater are typically segregated and collected in different oil pits for residual oil recovery (Khalid and Wan Mustafa, 1992). The recovered sludge oil is poor in quality and will not be included in the production of oil. Instead, these oils are drummed and sold as technical oils for non-edible applications (Ma, 1991; 1999). After oil recovery, the two waste streams mix together with the hydrocyclone wastewater to form a mixed wastewater or the POME. In general, the POME when fresh is hot, acidic, thick and viscous brownish or grey slurry. It has very high organic matter and is said to be 100 times as polluting as the domestic sewage (Ma and Augustine Ong, 1985; Khalid and Wan Mustafa, 1992). POME is a colloidal mixture of water, oil, and fine suspended components. The suspended components are mainly vegetative matters like cell walls, organelles, short fibres, water-soluble carbohydrates ranging from hemicelluloses to simple sugars (glucose, reducing sugars, and pectin), nitrogenous compounds (from proteins to amino acids), free organic acids, lipids, as well as the assembly of minor organic and mineral constituents (Edewor, 1986; Foo and Hameed, 2010; Ma, 1991). Wu et al. (2009) further reported the presence of Pentose, which is a building unit of insoluble carbohydrate. The suspended solids in POME slurry are mainly cellulose matter mixed with small portions of residue oil. The effluent is also reported to be non-toxic as the entire milling process does not use any chemical (Ma and Augustine Ong, 1985; Khalid and Wan Mustafa, 1992; Igwe and Onyegbado 2007). 
Nonetheless, the remaining $50 \%$ or about 0.75 cubic meters of water used in the milling of palm oil are used water which does not combine in the POME effluent streams. Having quite a similar quantity with the POME, the used water could cause loss of water to the environment, either to the drains, adjacent rivers of the palm oil mills, or through evaporation. Piping leakages and wash waters used to flush the machineries are other sources of water loss to the environment. Indeed, a large portion of water are actually lost in the form of steam/vapour. Steam is a main form of energy used in the palm oil mills (Sommart and Pipatmanomai, 2011). Most processes rely on the consumption of steams and hot water during crude palm oil extraction. Steam lost through exhaust gases from the sterilizer was reported by Chavalparit et al. (2006) and DOE (1999).

With a large amount of water loss in the palm oil milling processes, several literature suggested ways to reduce water consumption and wastewater discharge from the factories. The palm oil industry can adopt source reduction, which is a highly desired effort and the highest rank in the federal hierarchy of integrated solid waste management (Tchobanoglous et al., 1993). In the context of water and wastewater, water conservation and minimization of effluent discharge are becoming highlighted issues, particularly in the palm oil industry. Among the driving forces to a better water management are the increasingly stringent environmental regulations, the palm oil industry's commitment to achieve sustainable palm oil, an intense scrutiny over the long-term health effects on human and nature, as well as the availability of clean water resources in the country is of paramount importance (Parthasarathy and Dunn, 2005). Reducing the quantity of POME can reduce the delivery of this wastewater to the treatment system to ease or lessen the cost of the ultimate treatment (Tchobanoglous et al., 2004). Several options available for water conservation and 
wastewater reduction in the palm oil industry include milling process modifications, housekeeping practices, and utilization or recycling of the POME.

Most palm oil milling process modifications were found to accomplish maximum oil recovery or to recover as much oil as possible because the higher content of oil and grease characterised a higher strength of the wastewater (Schuchardt et al., 2007; Thanh et al., 1980). Thanh et al. (1980) reported a closed-system which can eliminate the release of effluent from the oil clarification room. A decanter as an extra unit between the vibrating screen and oil clarifier was used to separate the minor solid materials from the crude palm oil. The settled oil sludge are delivered to the three-phase nozzle centrifuge for oil recovery, the recovered oil are sent back to the clarifier, the sludge will have land application while the liquid phase are recycled back to press and oil clarifier to make up the dilution water. Thanh et al. (1980) also described the dry process where a wind silo is used to separate kernels from cracked shells by gravity. No water consumption is involved, but the variation of electricity voltage occurred in mills resulted in high kernel loss. On another hand, Schuchardt et al. (2007) suggested the application of a new sterilization process which does not generate condensate. The conventional autoclave sterilizer and a new oil recovery process can produce 0.45 cubic meters of POME per tonne of FFB processed while the new sterilizer process and new oil recovery process only produce 0.25 cubic meters of POME per tonne of FFB processed.

There are several in-plant control and housekeeping measures suggested by the Malaysian Department of Environment to optimize water use (DOE, 1999). Regular maintenance to avoid leaks in water pipelines and valves, skilled operation of the hydrocyclones to reduce 
water usage, control of overflow in the press room and clarification room, as well as regular equipment maintenance to prevent excessive wash-down are some of the cleaner production measures described (Thanh et al., 1980). Installation of the trigger release valve on the end of each hose is a cost effective approach in water-saving. Palm oil mill staff should be wellinformed about the importance of water conservation. Simple practices like shutting off valves, water taps, and water hoses immediately after use in addition to ceasing of flushing out spillages of oil and remnants into drains can avoid the profligacy of water (Thanh et al., 1980). Other approaches of cleaner production include control of oil clarification temperature, proper design and operation of oil traps, separation of effluent and storm water drainage systems, as well as proper interim storage of solid waste materials (DOE, 1999; Thanh et al., 1980). In Malaysia, the national average POME generation rate from palm oil mills are 0.67 to 0.75 cubic meters per tonne of FFB processed (Ma, 1999; $\mathrm{Ng}$ et al., 2011). If the factory is well-managed and good housekeeping practises are implemented, the amount can be auxiliary reduced to only 0.5 cubic meters for the handling of one tonne of FFB (DOE, 1999). The national average for Thailand on the other hand is 0.60 to 0.89 cubic meters of POME per tonne of FFB processed (Chavalparit et al., 2006; Chungsiriporn et al., 2006).

Another option is to utilize or recycle the POME, where the effluent is seen as a cheap renewable residue rather than a kind of wastes to be disposed (Salihu and Alam, 2012). Indeed, it is a wasteful exercise to spend money to treat this high amount of POME followed by releasing the effluent without further constructive applications. Treated effluent that is good in quality can be directly used as feed water for boiler or hydrocyclone (DOE, 1999). Turbines cooling water can be recirculated in-plant while the steam condensates can be reused for the purpose of processing, cleaning, and washing (Thanh et al., 1980). A study 
which recycles the sterilizer condensate and cooling water to the processing unit has reduced to $65 \%$ freshwater consumption and $67 \%$ wastewater generation. The clarification wastewater too was channelled to the processing unit as mixing water, the decanter as blending water, and to the separator as balancing water (Chungsiriporn et al., 2006). Besides, partially-treated POME which contained substantial quantities of valuable nutrients is useful for cropland application, particularly in fruits and vegetables' growth (Abdullah, 1992; DOE, 1999; Lim et al., 1991; Lim and Zaman, 1992; Salihu and Alam, 2012; Sulaiman et al., 2011). Hence, use of the inorganic fertilizers of the oil palm plantations or other croplands can be reduced. Schuchardt et al. (2007) also suggested the utilization of EFB and POME in a combined-composting process which can fulfil the demand of sustainable palm oil production. The process involved biological drying of the POME to produce much of compost for agricultural applications.

Other than the information on liquid POME, Fig. 2 also presented a mass balance for the processing of 1,000 kg of palm fruits (Chan, 1999; DOE, 1999; Ma et al., 1993; PORIM, 1985). The steam sterilization process results in $900 \mathrm{~kg}$ of sterilized FFB whereby $100 \mathrm{~kg}$ were lost as moisture and another $0.3 \mathrm{~kg}$ were oil in the condensate. The subsequent stripping /threshing mechanism for fruit-stalk separation can produce $666 \mathrm{~kg}$ of fruitlets and $234 \mathrm{~kg}$ of EFB. Indeed, the generation of EFB is represented as $23 \%$ of FFB processed in the palm oil mills (Ma, 1991; Prasertsan and Prasertsan, 1996; Sridhar and AdeOluwa, 2009). The EFB contained $152 \mathrm{~kg}$ of water, $82 \mathrm{~kg}$ of non-oily solids, and oil of less than $1 \mathrm{~kg}$. Under high pressure, the crude oil is extracted from the digested mash of fruitlets by use of the screw presses. The crude oil slurry is fed to a clarification system whereby the mass balance denotes further use of $173 \mathrm{~kg}$ of diluted water in the extraction of crude palm oil of $225 \mathrm{~kg}$ (approximately 20\% from FFB) (Sridhar and AdeOluwa, 2009). The bottom-phase or sludge 
waste is $180 \mathrm{~kg}$. On the other hand, the press cake is conveyed to a depericarper whereby press cake fibre of $180 \mathrm{~kg}$ and nuts are segregated. Press fibre cake generation is about $13.5 \%$ of FFB processed and constitutes $74 \mathrm{~kg}$ water, $97 \mathrm{~kg}$ non-oily solids, and $9 \mathrm{~kg}$ oil (Ma, 1991; Prasertsan and Prasertsan, 1996; Sridhar and AdeOluwa, 2009). Further processing of nuts will produce total shell of $73 \mathrm{~kg}$ (water $15 \mathrm{~kg}$, non-oily solids $57 \mathrm{~kg}$, oil $1 \mathrm{~kg}$ ) and total kernels of $67 \mathrm{~kg}$ (water $14 \mathrm{~kg}$, non-oily solids $19 \mathrm{~kg}$, oil $34 \mathrm{~kg}$ ). In terms of percentage of waste generation in palm oil processing, shells and kernels are 5.5\% and $6 \%$ of FFB processed respectively (Ma, 1991; Prasertsan and Prasertsan, 1996; Sridhar and AdeOluwa, 2009). Finally, potash ash generation is reported to be $0.5 \%$ of FFB (DOE, 1999).

(Figure 2 goes approximately here.)

Fig. 2 - Typical palm oil milling processes in addition to the sources of water pollution and by-products generation from processing of one tonne of FFB.

\subsection{Laws and legislations governing the industry}

In the 1970s, exponential growth of the palm oil industry resulted in severe environmental problems. The Department of Environment (DOE) is hence liable for implementing and enforcing environmental regulations against the industry. Among the regulations applied to palm oil industries' waste management practices are:

(1) Environmental Quality (Prescribed Premises) (Crude Palm Oil) Regulations, 1977

(2) Environmental Quality (Clean Air) Regulations, 1978

(3) Environmental Quality (Scheduled Waste) Regulations, 2005 
Among the listed regulations, the Environmental Quality (Prescribed Premises) (Crude Palm Oil) Regulations, 1977, is predominantly discussed. The regulations had specified detailed provisions to be complied. Most attention is drawn to the limits for parameters of effluent to be discharged into a watercourse or onto land. An increasingly stringent discharge limit into a watercourse is shown in Table 2 as in the Second Schedule, under Regulation 12(2) and 12(3). For discharges onto land, the $\mathrm{BOD}_{3}$ value should not surpass $5,000 \mathrm{mg} \mathrm{L}^{-1}$ (Legal Research Board, 2008).

(Table 2 goes approximately here.)

Table 2 - Parameter limits for watercourse discharge.

To progress towards a cleaner environment, the DOE is planning to revise a more stringent discharge limit to be imposed on effluent management. As stated in Regulation 12(4) - for watercourse discharge and 13(6) - for discharge onto land, the Director General can impose a more stringent limit if it is necessary. Above and beyond, there is an attempt to impose $20 \mathrm{mg}$ $\mathrm{L}^{-1} \mathrm{BOD}_{3}$ discharge limit on crude palm oil mill effluent. The scope of the discharge limit covers environmentally sensitive areas such as tourism areas of East Malaysia (Sabah and Sarawak States), and those locations in close proximity to water intake points. Since then, the $20 \mathrm{mg} \mathrm{L}^{-1}$ discharge limit concerns have been circulating among the administrators, millers, and researchers, as it is a challenge to be accomplished.

\section{LIQUID WASTE TREATMENT}

As the paper emphasizes POME tertiary/polishing treatment, typical or conventional effluent treatment systems adopted by palm oil millers are briefly reported. Past review works on POME treatment technologies are divided into categories such as aerobic digestion, anaerobic 
digestion, and physicochemical methods. This paper departs from typical treatment methods based on means of effluent discharge and hope to provide a different view for a better appreciation and understanding of these well-established systems.

\subsection{Discharge into inland watercourse}

Types of wastewater treatment options selected are based on the miller's preferences, the mill location, and land availability to cater for the wastewater treatment plant (Ma, 1999). Out of 416 licensed prescribed premises, 267 mills have been given the permission to discharge their liquid wastes into inland watercourse in the year 2009 (DOE, 2009). Normally, (1) the ponding system as well as (2) the open tank digester and extended aeration system effluent are discharged into inland watercourse. The criteria leading to the grant of licence for giving permission includes (Legal Research Board, 2008):

a) Whether it would be practical to adapt the existing equipment, control equipment or industrial plant to conform to given conditions;

b) The economic life of the existing equipment, control equipment or industrial plant, having regard to the date of purchase;

c) The quantity or degree of cut-back of emission, discharge or deposit of wastes to be achieved;

d) The estimated cost to be incurred by the licensee to comply to the given conditions; and

e) The nature and size of the trade, process or industry being carried out in the premises.

The specification of the characteristics of these wastes is as listed in Table 2 (Legal Research Board, 2008). 
The ponding system is the most popular method adopted by more than $85 \%$ of palm oil mills (Ma, 1999). Ponding in general includes wastes stabilization lagoons (ponds) and oxidation ponds. Oxidation ponds on the other hand can be loosely categorized as aerobic, facultative, and maturation ponds, otherwise as facultative ponds when oxygen is deficient (Wong, 1980).The ponding system normally includes sand and oil traps, cooling ponds, acidification ponds, anaerobic ponds, facultative ponds, and aerobic ponds (in descending order). Manually operated sand and oil traps are pre-treatment unit operations. In cooling ponds, the raw POME is cooled down to lower than $35^{\circ} \mathrm{C}$ prior to feeding into subsequent ponds (Thanh et al., 1980). Aerobic ponds are usually constructed up to 1-1.5 m deep while the anaerobic ponds are usually 5-7 m deep, both in earth structure without lining. The organic loading rate differs from $0.2-0.35 \mathrm{~kg} \mathrm{BOD} \mathrm{m}^{-3}$ day $^{-1}$ (Ma, 1999). Anaerobic ponding can digest high amount of solids and is inexpensive, but requires long retention times and a huge land area, with solids accumulation frequently reported (Hojjat, 2009). Solids reaching $4.8 \mathrm{~kg}$ volatile solids $\mathrm{m}^{-3}$ day $^{-1}$ can be digested in anaerobic ponds (Khalid and Wan Mustafa, 1992). Retention time is 20 days in anaerobic ponds (Yacob et al., 2006a). In due course of operation, solid sludge will accumulate at the bottom of the pond where desludging/desilting is eventually required. In brief, the ponding system entails low maintenance, it is economical, it offers process and operational simplicity, and is a feasible means of treating high strength organic wastewater. However, a huge land area (1 ha to 5 ha) and long hydraulic retention times (HRT 40 to 200 days) are required (Thanh et al., 1980; Wong, 1980). In terms of dimension, a typical size of an anaerobic pond is $60.0 \times 29.6$ X 5.8 m (length $\mathrm{x}$ width $\mathrm{x}$ depth), taking a palm oil mill which has a processing capacity of 54 tons per hour as an example. Size of pond depends on the capacity of the palm oil mill as well as the area available for ponds (Yacob et al., 2006a). Solids accumulated may reach 31,500 $\mathrm{mg} \mathrm{L}^{-1}$ before ponding begins, but are removed during the process by suction pumps. After the 
decanter-dryer and ponding treatment, about $130 \mathrm{mg} \mathrm{L}^{-1}$ could be reached at the final discharge (Ma and Ong, 1985).

Another common system applied is the conventional anaerobic-aerobic system (open tank digestion and extended aeration) (Chan et al., 2010). The two-phased anaerobic digestion consists of mild steel-made digesters which are open at the top and left unstirred. POME with organic loading rates from 0.8-1.0 BOD m $\mathrm{m}^{-3}$ day $^{-1}$ undergoes approximately 20 days of HRT in the anaerobic digesters. Open tank digesters are capable of removing chemical oxygen demand (COD) by $81 \%$ (Yacob et al., 2006b). Subsequently, the effluent is further treated in extended aeration ponds for additional reduction in COD and BOD. The HRT of the extended aeration pond is 10 days (Ugoji, 1997). Mechanical surface aerators are used to supply air to the treatment plant with HRT of about 40 days (Ma, 1999; Chan et al., 2010). Supernatant is then discharged into a close by watercourse.

\subsection{Land disposal}

The second most favoured POME discharge manner is accounted for 96 licensed prescribed premises that practiced land disposal (DOE, 2011). Supernatant from the (1) ponding system (typically anaerobic ponds) or (2) treatment ponds in the decanter-drier system, (3) stirredtank digested POME, as well as (4) aerobic and (5) anaerobic digester bottom sludge are sources of POME utilized for controlled land application techniques (Ma, 1991; Ma, 1999; Zakaria et al., 2000). Through pond digestion processes, the nutrient content particularly nitrogen and potassium will go down through leaching and settling of sludge solids at the pond underneath. In contrast, tank digestion with agitation and stirring of effluent cause negligible effects to nutrient content. This mechanism breaks down complex organic solids for enhancing nutrient uptakes by plants (Zakaria et al., 1995). 
In general, closed tank digesters coupled with biogas recovery facilities are associated with land application (Ma, 1999). In comparison with open tank anaerobic digesters, closed tank anaerobic digesters are more efficient in removing COD (> 95\%) at a lower HRT of 17 days (Yacob et al., 2006b). Closed systems also generate biogases which are eventually either converted to electricity in a biogas engine or burned into gas flare. In some cases, biogas can be used as fuel in modified diesel engines with induction motors to produce electricity (Puetpaiboon and Chotwattanasak, 2004). On the other hand, effluent from an open tank digester and extended aeration discussed in the preceding session are also discarded to land application, mainly for irrigation. The raw or partially treated POME is applied to land either by discharging to overland flow or applying directly for irrigation (Thanh et al., 1980). Commercial scales of land application systems have been highlighted (Zakaria et al., 1995; DOE, 1999; Lim et al., 1999) as below and their corresponding advantages and disadvantages are shown in Table 3:

- Sprinkler / pipe irrigation system,

- Furrow / gravity flow system,

- Tractor / tanker / pump system,

- Longbed system, and

- Flatbed system.

(Table 3 goes approximately here.)

Table 3: Advantages and Disadvantages of the various POME land application methods.

With regard to environmental concern, research has publicized that land application of POME at controlled loading rates has insignificant impact on soil and water resources 
(Zakaria et al., 1995). Although POME is highly polluting, no toxicity is reported due to zero

chemical addition throughout the wet milling process. POME nutrients and minerals could be accumulated by carrying out a stand-alone or off palm oil mills waste management strategy such as evaporation. The concentrated effluent is rich in plant nutrients, especially nitrogen (950 $\mathrm{mg} \mathrm{L}^{-1}$ ), phosphorous (150 $\left.\mathrm{mg} \mathrm{L}^{-1}\right)$ and potassium (1,960 $\mathrm{mg} \mathrm{L}^{-1}$ ) (DOE, 1999). It is therefore a good raw material for making fertilizer (Panda, 2013). Research also has revealed that no heavy metal accumulation has been detected in the soil, water and the crop in longterm POME receiving lands (DOE, 1999).

\subsection{Composting}

According to DOE (2011), 12 licensed prescribed premises in Malaysia were granted the permission to practice solitary composting. In most cases, anaerobic liquor from anaerobic ponds, and anaerobic sludge from open or closed anaerobic digested tanks are used for composting treatment at field scale. EFB are pressed and shredded upon collection for crude palm oil recovery. The pressed-shredded EFB are brownish in colour with a length size of 15$20 \mathrm{~cm}$. EFB act as the main carbon source for the composting treatment due to its high cellulose and hemicelluloses content. By percentage of EFB, cellulose and hemicelluloses were 52.8 and $14.8 \%$, respectively (Baharuddin et al., 2010); while the anaerobic POME sludge is a nutrient source reported for composting with high concentrations of nitrogen (3,600 mg L $\left.{ }^{-1}\right)$, phosphorus $\left(1,200 \mathrm{mg} \mathrm{L}^{-1}\right)$, potassium $\left(2,400 \mathrm{mg} \mathrm{L}^{-1}\right)$, and magnesium $(1,500$ $\left.\operatorname{mg~L}{ }^{-1}\right)(\mathrm{Ma}, 1991)$.

The thickened anaerobic POME sludge from the bottom part of the clarifier tank is used for composting treatment. The total POME anaerobic sludge added into the EFB compost 


\subsection{Other Methods}

Above and beyond the three key distinctive disposal approach as reported above, other mills' practised subsequent disposal schemes (DOE, 2011):

- Discharge into inland watercourse and land disposal (32 licensed prescribed premises)

- Discharge into inland watercourse and composting (3 licensed prescribed premises)

These mills applied a combination of disposal methods. With such combination of the disposal processes, it offers process flexibility and perhaps better control of each of the treatment unit operations. Whatever treatment options are in operation, records of enforcement have shown that the Malaysian palm oil industry is generally complying with the prevailing national regulation of $100 \mathrm{mg} \mathrm{L}^{-1} \mathrm{BOD}_{3}$ for inland watercourse disposal and $5,000 \mathrm{mg} \mathrm{L}^{-1} \mathrm{BOD}_{3}$ for land disposal. Successful pollution abatement and emerging demand 
to fulfil the local requirement for better environmental protection has urged the DOE to further revise the national regulation to a more stringent $\mathrm{BOD}_{3}$ discharge limit.

\section{POME POLISHING / TERTIARY TREATMENT TECHNOLOGIES}

As satisfying results are shown by the existing POME primary/secondary treatment technologies, POME polishing systems pull attention to further remove organic matters, total suspended solids, and colour reduction. Since the $20 \mathrm{mg} \mathrm{L}^{-1} \mathrm{BOD}_{3}$ discharge limit came into enforcement, most polishing technologies are found incapable of performing consistently and continuously. The enforcement record is showing $95.5 \%$ compliance and in order to attain 100\% compliance, the DOE discharge standard may need to be reviewed (DOE, 2011). Total suspended solids are frequently regarded as contributing to high BOD in the effluent. As such, attempts to filter out suspended solids through application of membrane separation technologies are rapidly made, optimistically to reduce BOD and suspended solids concomitantly in the final discharge. On the other hand, colour removal is attaining consideration as the final effluent is still in dark brownish colour. From an aesthetic point of view, colour treatment is receiving considerable attention particularly in tourism and environmentally sensitive areas.

Tables 4 and 5 present a synopsis of POME polishing/tertiary treatment technologies. Such attempt to gather the sporadic POME polishing/tertiary treatment research for the first time may nonetheless offer the palm oil industry an insight for better effluent management.

(Table 4 goes approximately here.)

Table 4 - Summary of technologies/systems in treatability studies for POME tertiary treatment/polishing. 
Treatability studies to polish POME accentuates on producing higher quality effluent while full scale polishing plants emphasize the discharge limit compliance. As most of the technologies in treatability studies are more advanced and costly, they are seen to progress towards water reclamation and recycling. Membrane technology is frequently reported to produce a higher quality treated effluent capable of recycling boiler feed water and to even be reclaimed as drinking water. Nik Sulaiman and Chea (2004) applied ultrafiltration (UF) with various membranes of molecular weight cut-off (MWCO) to polish biologically treated POME. The study suggested that membrane with higher MWCO produced higher fluxes but lower MWCO produced better quality permeate. However, colour removal was ineffective when applying membrane technology alone after the conventional ponding system. Findings from a more recent study by Idris et al. (2010) suggested that pre-treatment of biologicallytreated POME before tertiary treatment using UF membrane resulted in better permeate quality. Biologically-treated POME from ponding systems was subject to physical pretreatment processes, namely coagulation and adsorption. Both processes were commonly applied to reduce SS from effluent. Permeate from UF membrane was found successful in COD, colour, and turbidity reduction.

Besides applying membrane technology in biologically-treated POME, the technology was also attempted on raw effluent (Ahmad et al., 2003; 2006). Raw POME was subjected to chemical and physical pre-treatment, consisting of coagulation (ferric chloride) and flocculation aid (acrylamide), sedimentation, and adsorption using activated carbon. Effluent was further treated using UF membrane and reverse osmosis (RO) membrane. The technology was successful in producing high quality effluent for water recycling. All reported cases above recommended that membrane technology is practical but only after it is 
Another technology attempted for tertiary treatment of POME was advanced oxidation processes (AOPs). The technology is basically chemical treatment using the highly reactive hydroxyl radicals $\left(\mathrm{OH}^{*}\right)$. A study conducted by Aris et al. (2008) applied Fenton oxidation to polish biologically treated POME. Two processes used were ambient-Fenton and solarFenton. The better performed solar-Fenton used oxidation mechanism and resulted in rapid degradation of organic compounds in POME which subsequently lead to colour reduction in the wastewater. Another study reported by Abdullah (2008) used the hydrogen peroxide photolysis method. In short, solar-Fenton performed well in colour reduction compared to COD whereas hydrogen peroxide photolysis performed better in COD reduction compared to colour. Both studies were still at laboratory-scale and important operating conditions such as reaction time, optimum $\mathrm{pH}$ and light intensity, dosage, as well as working volumes are subjected for further detailed exploration. Nonetheless, the viable results on COD and colour removal offered insights on the feasibility of AOPs as one of the POME polishing technologies. 
Other than physical and chemical approaches, biological methods were also attempted to polish biologically-treated POME. POME from the conventional ponding systems had gone through activated sludge processes in anaerobic, anoxic, and aerobic conditions. Biological polishing systems applied more advanced biological processes such as bioreactor systems, attached growth systems, and granular sludge technologies. Zahrim et al. (2009) applied suspended activated sludge system in sequencing batch reactor (SBR) to polish anaerobically-treated POME. Colour removal was attained at about $0-14 \%$ while organic matter removal was at about $27-39 \%$ only. The study later applied an attached growth system where granular activated carbon was seeded with activated sludge in a SBR. The system was described to remove colour at about $28-41 \%$ while organic matter removal was at about 59$70 \%$. High percentage of colour and COD removal in the latter system was reported due to the adsorption of colour compounds into the granular activated carbon while biofilm growth on the surface further oxidise the colour compounds. Biodegradation and adsorption mechanisms contributed $50 \%$ each in recalcitrant pollutant removal in this case. Chan et al. (2010) similarly applied SBR for the post-treatment of anaerobically-treated POME. The technology was positively applied (at laboratory scale) to accomplish significant COD, BOD, and SS removal due to the factors like high biomass acclimation during bioreactor start-up, high retention of mixed liquor volatile suspended solids (MLVSS), and good settleability of activated flocs.

In addition to independent biological processes, a more recent and popular technology to integrate biological and physical separation was frequently reported in POME tertiary treatment. For instance, Ahmad et al. (2009) evaluated a hybrid membrane bioreactor (MBR) system to sequentially treat raw POME in a series of activated sludge processes of anaerobic, 
anoxic, and aerobic reactors followed by membrane separation in the aerobic zone. However, the membrane system experienced fouling in long-term operation and membrane cleansing did not restore the initial permeability. On the whole, the membrane technology is still capable of treating POME significantly and produce a good quality effluent.

Essentially, almost all kind of wastewater treatment technologies established have been attempted to be applied in POME treatment and polishing treatability studies (either laboratory or pilot-scales). Physicochemical and biological processes are performing satisfactorily to manage POME. The key issues are still the applicability and practicality of these technologies after considering several factors such as cost-effectiveness, operational consistency, and system sustainability if operated as full-scale treatment plants in palm oil mills in the future. Furthermore, POME's unique characteristic as organic, non-toxic, highly coloured and existence of recalcitrant organic compounds in the wastewater are crucial features to be considered in order to implement the full-scale technologies beyond labdeveloped researches. Extensive research is needed to narrow down the practicality gap between treatability studies and full-scale treatment plants. Among some attention-grabbing issues could be, but not limited-to, are scale-up studies, operational troubleshooting in fullscale treatment plants, fundamental wastewater and technological researches to gain better understanding of unit processes, process optimization, as well as operational flaws identification.

(Table 5 goes approximately here.)

Table 5 - Summary of full scale technologies / systems for POME tertiary treatment / polishing. 
Compared to treatability studies, full-scale treatment plants as listed in Table 5 are more matured tertiary treatment technologies ready for commercialization. While no previous reports or summaries of all the commercially available tertiary treatment technologies in Malaysia were found, information of the technologies reported in this paper were collectively taken from notes and presentations of seminars and workshops, as well as through verbal survey to the participated palm oil millers and sporadic internet resources. Also, these technologies reported are offered by the technology providers, no information and laboratory data are available however, on the system performance. The purpose of the assortment of polishing technologies here is to provide important and first-hand information on available options, typical processes used, and appreciation of these readily-available technologies as a way towards better management of the POME.

The use of MBR has been reported by Sulong et al. (2007). The membrane installation is aimed to replace the secondary clarifier after biological treatment in anoxic and aerobic activated sludge processes. Among the benefits of membrane instead of clarifier are smaller footprint, the ability for high solids concentration retention, and producing effluent appropriate for reuse in the palm oil mills. The cost reported is about RM 2.3 million for a typical 40 tonnes FFB $\mathrm{hr}^{-1}$ mill. Other MBR offer was reported by Moro (2010) where submerged membrane was installed in both anaerobic and aerobic tanks. Besides, a biological-physicochemical treatment process technology was also announced by the MPOB (Sulong and Abdul Wahab, 2008). The combined and compact biological-chemical-physical treatment process offered SS, ammonia, and colour reduction through its odour-free treatment to produce treated effluent accomplished for water reuse. A small footprint plant (only $40 \%$ 
compared to conventional activated sludge processes) producing high quality and reusable effluent is probable at the costs of about RM 1.4 million for a 30 tonnes FFB $\mathrm{hr}^{-1}$ mill.

The POME tertiary treatment (polishing) technology is expected to be consistent, sustainable, and inexpensive. Most systems offered by the technology providers ranged in costs of between RM 1.5 to 2.0 million. To cater to the criteria of sustainability, chemical addition or processes which required high energy consumption are hence unfavourable. Resource recovery of the palm oil milling by-products as well as water reclamation are usually incorporated as a marketing strategy in the commercial polishing systems. The criteria of providing a system with consistent performance is the remaining concern to address. Enquiries made to the Malaysian Palm Oil Board (MPOB) were able to inform that several technologies for technological transfer from pilot tests to actual palm oil mills installation are still ongoing and will be published when completed.

The POME is generally organic waste, where presence of recalcitrant organic compounds makes the effluent obstinate to treat. Thus, most full-scale treatment technologies are actually advanced biological processes or biological-based technology integrated with chemical or physical treatments. For instance, an SBR-constructed wetland was introduced by Chong and Tan (2010) to bring the $\mathrm{BOD}_{3}$ of treated effluent below $20 \mathrm{mg} \mathrm{L}^{-1}$ and as a potential system for water recycling. Partially-treated effluent from anaerobic digestion with BOD:N:P ratio of 100:46:4.0 (20 days HRT) entered the SBRs. SBRs represented secondary treatment and the process is similar in concept with activated sludge system. Treated effluent was reported to contain approximately $27 \mathrm{mg} \mathrm{L}^{-1}$ of $\mathrm{BOD}_{3}$ and $213 \mathrm{mg} \mathrm{L}^{-1}$ of SS. The effluent then entered an aquatic processing unit containing cattails plant. The system was a form of constructed 
Besides full biological systems, Chong (2010) introduced a tertiary treatment system to be incorporated with the conventional ponding system. The biological system was applied, followed by chemical coagulation (400-700 $\left.\mathrm{mg} \mathrm{L}^{-1}\right)$, flocculation $\left(4-7 \mathrm{mg} \mathrm{L}^{-1}\right)$, and physical treatment (sedimentation). Also the addition of lactic acid bacteria, yeast and photosynthetic bacteria during the biological phase is reported. The final stage was a multi-media filtration treatment to reduce SS in the final effluent. Bacteria decomposed both organic and inorganic materials in addition to reducing the organic matter to a soluble state, henceforth turning into food sources for other microbes. Enzymes catalyst secreted by the microbes will break down complex organic material into smaller substances. Further oxidation and purification processes ensure a stabilized effluent suitable for final polishing in the subsequent chemical and filtration treatment. Jurgensen (2010) also reported a combined biological-chemical technology to treat POME. The working principle is laid on application of ozone technology as pre-treatment to the submerged fixed-film bioreactor. Ozone is an important oxidizer used to break down the hardly biodegradable organic matters in POME. Once the organic compounds were oxidized, the left-over organic matter was readily biodegradable in the bioreactor with an active biofilm surface area of about $300 \mathrm{~m}^{2} \mathrm{~m}^{-3}$. The only technology reported without any biological component was described by Barr (2010). The technology comprised of 4 phases, namely coagulation, flocculation, separation, and discharge. An important feature of the technology was in the control of the sludge settleability. With the 
In a glance, suspended and attached growths advanced biological processes are principally employed in full-scale wastewater treatment plants due to the organic-based wastewater characteristics. Attached growth systems are usually favoured because the system demonstrates higher organic loading capabilities, hence increasing the potential for treating high organic waste loads per unit volume. Higher density of bacterial population, better tolerance to process upset, smaller footprint, less expensive, and quick start-up are other advantageous features of the system in comparison with suspended growth processes (Steiner, 2000). Membrane filtration processes give very clear colour effluent, and are usually integrated for water reclamation and reuse. Moreover, physicochemical treatment approaches are allied with colour removal and bio-solids / sludge reduction in the final effluent.

Efforts for better environmental management of the Malaysian palm oil industry have been consecutively executed over the decades. It is known that the ponding system used for POME treatment is not sufficient, thus various researches have been conducted and almost all kinds of technologies have been reported to treat POME. Surprisingly, the new $\mathrm{BOD}_{3} 20 \mathrm{mg} \mathrm{L}^{-1}$ discharge limit is so challenging to the industry inspite of all the technologies attempted. The major research issue is to meet the $20 \mathrm{mg} \mathrm{L}^{-1} \mathrm{BOD}_{3}$ discharge standard and this has been a challenge with the amount of research reported on treatment of POME. Therefore, BOD, SS, 
and colour are still parameters to be removed and are issues before an attempt to reach zero discharge is achieved.

High or low processing of FFB seasons in a year produced different loadings of incoming POME into the polishing plants. Incompetent operation and maintenance worsen the situation where some technologies were unable to perform optimally. Sludge removal and subsequent beneficial application of these biomasses should be granted more consideration. Colour causing compounds in the wastewater are known. Whether applying specific microbial agent can break down these organic compounds is a challenge. Apparently some plant constituents such as carotene, phenolic compounds, polyphenols, tannin and lignin, or melanoidin are sources of the colour in POME (Neoh et al., 2013; Oswal et al., 2002; Limkhuansuwan and Chaiprasert, 2010). Another point in support of the argument is, it is noticed that most POME research nowadays are referring to old information such as the milling process and wastewater characteristics. As the industry progress vigorously over the years, many factors should be investigated in order to get further insights of POME management. Introduction of hybrid palm fruits and several other new species, improved milling processes due to technological advances, as well as water resources used in palm oil mills (supplied by water companies, self-treated, or recycled) could be clues to new evidence on the exploration and innovation for a breakthrough in palm oil wastewater research.

\section{CONCLUSIONS}

Intensive and dynamic research on POME pollution abatement has paid off efficaciously, and the Malaysian palm oil industry is leading the trend towards sustainable palm oil production. As a roadmap to palm oil zero emissions, POME polishing should be accomplished either for water reclamation, reuse, or absolute pollution abatement. Apart from the recognised 


\section{Acknowledgements}

The authors gratefully acknowledge the financial support from Universiti Teknologi Malaysia (UTM) and Ministry of Education (Q.J130000.2508.01H53). The authors would also like to thank the Department of Environment (DOE Putrajaya Office and Johor Bahru Branch) and all palm oil millers for facilitating this study. Special acknowledgment is extended to Gustaf Olsson (Emeritus Professor) from Lund University for proof reading the article.

\section{References}

Ab Rahman, Z., Menon, N.R., Kandiah, S., Mohamed Halim, R. and Alias, H. 2011. Development in palm oil milling technology. In Wahid, M.B., Choo, Y.M. and Chan, K.W. (Ed.) Further advances in oil palm research (2000-2010). (Volume 2) (pp. 599609), Malaysia: Malaysian Palm Oil Board. 
Abdullah S., 2008. Tertiary Treatment of Palm Oil Mill Effluent (POME) using Hydrogen Peroxide Photolysis Method. Master thesis, Department of Civil Engineering (Environmental), Universiti Teknologi Malaysia.

Abdullah, C.T., 1992. The effects of POME on bris soil characteristics. Teknol. Tembakau. 8, 35-39.

Ahmad, A. L., Chong, M. F., Bhatia, S. and Ismail, S., 2006. Drinking water reclamation from palm oil mill effluent (POME) using membrane technology. Desalination. 191, 3544.

Ahmad, A. L., Ismail, S. and Bhatia, S., 2003. Water recycling from palm oil mill effluent (POME) using membrane technology. Desalination. 157, 87-95.

Ahmad, Z., Ujang, Z., Olsson, G. and Abdul Latiff, A. A., 2009. Evaluation of hybrid membrane bioreactor (MBR) for palm oil mill effluent (POME) treatment. International Journal of Integrated Engineering (Issue on Civil and Environmental Engineering). 1725.

Aris, A., Ooi, B. S., Kon, S. K. and Ujang, Z., 2008. Tertiary treatment of palm oil mill effluent using fenton oxidation. Malaysian Journal of Civil Engineering. 20(1), 12-25.

Baharuddin, A. S., Lim, S. H., Md Yusof, M. Z., Abdul Rahman, N. A., Md Shah, U. K., Hassan, M. A., Wakisaka, M., Sakai, K. and Shirai, Y., 2010. Effect of palm oil mill effluent (pome) anaerobic sludge from $500 \mathrm{~m}^{3}$ of closed anaerobic methane digested tank on press-shredded empty fruit bunch (EFB) composting process. African Journal of Biotechnology. 9(16), 2427-2436.

Baharuddin, A. S., Wakisaka, M., Shirai, Y., Abd Aziz, S., Abdul Rahman, N. A. and Hassan, M. A., 2009. Co-composting of empty fruit bunch and partially treated palm oil mill effluent in pilot scale. International Journal of Agric. Res. 4, 69-78. 
Barr, G., 2010. Chemical and physical polishing of POME treatment. Seminar \& Workshop on Palm Oil Mill Effluent Tertiary Treatment Technologies $\left(\right.$ POMET $\left.^{3}\right)$, Kota Kinabalu, Sabah, Malaysia.

Basiron, Y., 2007. Sustainable palm oil practices in Malaysia, Malaysia: Malaysia Palm Oil Council.

Chan, K.W., 1999. Biomass production in the oil palm industry. In Oil Palm and the Environment. Singh, G., Lim, K.H., Teo, L. and David Lee, K. (edn), Malaysia: Malaysian Oil Palm Growers' Council.

Chan, Y. J., Chong, M. F. and Law, C. L., 2010. Biological treatment of anaerobically digested palm oil mill effluent (POME) using a lab-scale sequencing batch reactor (SBR). Journal of Environmental Management. 9, 1738-1746.

Chavalparit, O., Rulkens, W.H., Mol, A.P.J. and Khaodhair, S., 2006. Options for environmental sustainability of the crude palm oil industry in Thailand through enhancement of industrial ecosystems. Environment, Development and Sustainability. 8, 271-287.

Chong, K. P. and Tan, K. K., 2010. A presentation for construction of a SBR-APU tertiary POME treatment / polishing plant. Seminar \& Workshop on Palm Oil Mill Effluent Tertiary Treatment Technologies (POMET ${ }^{3}$ ), Kota Kinabalu, Sabah, Malaysia.

Chong, M. T., 2010. Bio-chem POME tertiary treatment system. Seminar \& Workshop on Palm Oil Mill Effluent Tertiary Treatment Technologies (POMET ${ }^{3}$, Kota Kinabalu, Sabah, Malaysia.

Chungsiriporn, J., Prasertsan, S. and Bunyakan, C., 2006. Minimization of water consumption and process optimization of palm oil mills. Clean Techn Environ Policy. 8, $151-158$. 
Cooper, I.W., 1983. Boiler operation, Proceedings of Regional Workshop on Palm Oil Mill Technology and Effluent Treatment, 48-57. (in Malaysia)

DOE, 1999. Industrial processes \& the environment (Handbook No. 3) - Crude palm oil industry, Malaysia: Department of Environment, Ministry of Science, Technology and the Environment.

DOE, 2011. Annual Report 2011, Report 983-9119-77-X, Malaysia: Department of Environment, Ministry of Natural Resources and Environment.

Edewor, J.O., 1986. A comparison of treatment methods for palm oil mill effluent (pome) wastes. J. Chem. Tech. Biotechnol. 36, 212-218.

Embrandiri, A., Singh, R.P., Ibrahim, H.M. and Ramli, A.A., 2012. Land application of biomass residue generated from palm oil processing: its potential benefits and threats. Environmentalist. 32, 111-117.

Foo, K.Y. and Hameed, B.H., 2010. Insight into the applications of palm oil mill effluent: a renewable utilization of the industrial agricultural waste. Renewable and Sustainable Energy Reviews. 14, 1445-1452.

Goa, W., Liang, H., Ma, J., Han, M., Chen, Z., Han, Z., Li, G., 2011. Membrane fouling control in ultrafiltration technology for drinking water production: A review Desalination. 272, 1-8.

Ho, C.C., Tan, Y.K. and Wang, C.W., 1984. The distribution of chemical constituents between the soluble and the particulate fractions of palm oil mill effluent and its significance on its utilization / treatment. Agricultural Wastes. 11(1), 61-71.

Hojjat, M., Mustapha, S. B. and Mohd Salleh, M. A., 2009. Optimization of POME anaerobic pond. European Journal of Scientific Research. 32(4), 455-459.

Idris, A., 2010. Biofil polishing plant for POME. Seminar \& Workshop on Palm Oil Mill Effluent Tertiary Treatment Technologies $\left(\right.$ POMET $\left.^{3}\right)$, Kota Kinabalu, Sabah, Malaysia. 
Idris, M. A., Jami, M. S. and Muyibi, S. A., 2010. Tertiary treatment of biologically treated palm oil mill effluent (POME) using uf membrane system: effect of MWCO and transmembrane pressure. International Journal of Chemical and Environmental Engineering. 1(2), 108-112.

Igwe, J.C. and Onyegbado, C.C., 2007. A review of palm oil mill effluent (pome) water treatment. Global Journal of Environmental Research. 1(2), 54-62.

Jurgensen, E. J., 2010. Ozone and submerged fixed film biological process of POME polishing plant. Seminar \& Workshop on Palm Oil Mill Effluent Tertiary Treatment Technologies $\left(\mathrm{POMET}^{3}\right.$ ), Kota Kinabalu, Sabah, Malaysia.

Khalid, A.R. and Wan Mustafa, W.A., 1992. External benefits of environmental regulation: resource recovery and the utilization of effluents. The Environmentalist. 12(4), 277-285.

Lam, M.K. and Lee, K.T., 2011. Renewable and sustainable bioenergies production from palm oil mill effluent (POME): win-win strategies toward better environmental protection. Biotechnology Advances. 29, 124-141.

Lim, K. H., Mohd Hashim, T., Zakaria, Z. Z., Singh, G. and Lim, C. H., 1999. Land application of palm oil mill effluent. In Oil Palm and the Environment. Singh, G., Lim, K.H., Teo, L. and David Lee, K. (edn), Malaysia: Malaysian Oil Palm Growers’ Council. Lim, S.P. and Zaman, I.K., 1992. POME technology - a hope for sandy soils. Teknol. BuahBuahan. 8, 31-34.

Lim, S.P., Abu Bakar, O. and Lee, C.S., 1991. Effect of POME and other organic wastes on starfruit grown on sand-tailings. Prosiding Symposium Buah-Buahan Kebangsaan. 198203.

Limkhuansuwan, V., Chaiprasert, P., 2010. Decolorization of molasses melanoidins and palm oil mill effluent phenolic compounds by fermentative lactic acid bacteria. J Environ. Sci. $22,1209-1217$. 
Lu, T. Y., 2010. Tertiary treatment system. Seminar \& Workshop on Palm Oil Mill Effluent Tertiary Treatment Technologies (POMET ${ }^{3}$ ), Kota Kinabalu, Sabah, Malaysia.

Ma, A. N., 1991. Latest developments in the management of palm oil industrial wastes in Malaysia. Ensearch. 5(2), 19-33.

Ma, A. N., 1999. Treatment of palm oil mill effluent. In Oil Palm and the Environment. Singh, G., Lim, K.H., Teo, L. and David Lee, K. (edn), Malaysia: Malaysian Oil Palm Growers' Council.

Ma, A.N. and Augustine Ong, S.H., 1985. Pollution control in palm oil mills in Malaysia., J. Am. Oil Chem. Soc., 62 (1985) 261-265.

Ma, A.N., Cheah, S.C. and Chow, M.C., 1993. Current status of palm oil processing wastes management. In Yeoh, B.G., Chee, K.S., Phang, S.M., Isa, Z., Idris, A. and Mohamed, M. (Ed.) Waste management in Malaysia: current status and prospects for bioremediation. (pp. 111-136), Malaysia: Ministry of Science, Technology and the Environment.

Legal Research Board, 2008. Environmental Quality Act 1974 (Act 127) \& Subsidiary Legislation. (pp. 1-62), Malaysia, Petaling Jaya: International Law Book Services.

Mohd Siran, Y., 2010. Industry Experiences with tertiary treatment systems: the sime darby experiences. Seminar \& Workshop on Palm Oil Mill Effluent Tertiary Treatment Technologies $\left(\mathrm{POMET}^{3}\right.$ ), Kota Kinabalu, Sabah, Malaysia.

Moro, M., 2010. Anaerobic and Aerobic membrane bioreactor for effluent treatment system. Seminar \& Workshop on Palm Oil Mill Effluent Tertiary Treatment Technologies $\left(\mathrm{POMET}^{3}\right)$, Kota Kinabalu, Sabah, Malaysia.

MPOB, 2012. $31^{\text {st }}$ edn, Malaysian Oil Palm Statistics 2011, Malaysia: Economics and Industry Development Division, Malaysia Palm Oil Board. 
Neoh, C.H., Yahya, A., Adnan R., Abdul Majid, Z., Ibrahim, Z., 2013. Optimization of decolorization of palm oil mill effluent (POME) by growing cultures of Aspergillus fumigates using response surface methodology Environ. Sci. Pollut. Res. 20:2912-2923.

Ng, F. Y., Yew, F. K., Basiron, Y. and Sundram, K., 2011. A renewable future driven with malaysian palm oil-based green technology. Journal of Oil Palm and the Environment. 2, $1-7$.

Nik Sulaiman, N. M. and Chea, K. L., 2004. Membrane ultrafiltration of treated palm oil mill effluent (POME). Jurnal Teknologi. 41(F), 113-120.

Oswal, N., Sarma, P. M., Zinjarde, S.S., Pant, A., 2002. Palm oil mill effluent treatment by a tropicalmarine yeast. Bioresour. Technol. 85, 35-37.

Panda, H., 2013. Palm Oil Mill Effluent Disposal on Land. The Complete Book on Biological Waste Treatment and their Utilization. (pp. 166-188), India: Niir Project Consultancy Services.

PEMANDU, 2010. Chapter 9: Deepening Malaysia's Palm Oil Advantage. In Economic Transformation Programme: A Roadmap for Malaysia, Malaysia: Prime Minister's Department. Performance Management and Delivery Unit (PEMANDU).

PORIM, 1985. Palm Oil Factory Process Handbook Part 1: General Description of the Palm Oil Milling Process, Malaysia: Palm Oil Research Institute of Malaysia, Ministry of Primary Industries.

Prasertsan, S. and Prasertsan, P., 1996. Biomass residues from palm oil mills in thailand: an overview on quality and potential usage. Biomass and Bioenergy. 11(5), 387-395.

Puetpaiboon, U. and Chotwattanasak, J., 2004. Anaerobic treatment of palm oil mill wastewater under mesophilic condition, Proceedings of $10^{\text {th }}$ World Congress Montreal, 989-994. (in Canada) 
Rashid, M., Ramli, M. and Rozainee, M., 1998. A field evaluation of particulate emission concentrations in the palm oil mill boilers. Jurnal Teknologi. 29, 1-6.

Rupani, P.F., Pratap Singh, R., Ibrahim, M.H. and Esa, N., 2010. Review of current palm oil mill effluent (pome) treatment methods: vermicomposting as a sustainable practice. World Applied Sciences Journal. 10(10), 1190-1201.

Salihu, A. and Alam, M.Z., 2012. Palm oil mill effluent: a waste or a raw material. Journal of Applied Sciences Research. 8(1), 466-473.

Schuchardt, F., Wulfert, K., Darnoko, D. and Herawan, T., 2007. Effect of new palm oil mill processes on the EFB and POME utilization. Proceedings of Chemistry and Technolotgy Conference PIPOC, 44-57. (in Kuala Lumpur)

Shahrudin, A. F., 2010. Roughing filter solid contact (RFSC) technology for POME polishing system. Seminar \& Workshop on Palm Oil Mill Effluent Tertiary Treatment Technologies $\left(\mathrm{POMET}^{3}\right.$ ), Kota Kinabalu, Sabah, Malaysia.

Sommart, K. and Pipatmanomai, S., 2011. Assessment and improvement of energy utilization in crude palm oil mill, Proceedings of the International Conference on Chemistry and Chemical Process IPCBEE, 161-166. (in Singapore)

Sridhar, M.K.C. and AdeOluwa, O.O., 2009. Palm oil industry residues. In Nigam, P.S. and Pandey, A. (Ed.) Biotechnology for agro-industrial residues. (pp. 341-355), Netherlands: Spinger Science + Business Media B.V.

Steiner, C. G., 2000. Understanding anaerobic treatment: recent enhancements to anaerobic treatment design translate into improved treatment efficiency. Pollution Engineering. February, 36-38.

Sulaiman, F., Abdullah, N., Gerhauser, H. and Shariff, A., 2011. An outlook of Malaysian energy, oil palm industry and its utilization of wastes as useful resources. Biomass and Bioenergy. 35(9), 3775-3786. 
Sulong, M. and Abdul Wahab, N., 2008. Compact Tertiary Plant for the Treatment of POME. MPOB Information Series, Malaysia: Malaysian Palm Oil Board.

Sulong, M., Lim, W. K., Kandiah, S. and Md Top, A. G., 2007. Membrane bioreactor technology for tertiary treatment of palm oil mill effluent (POME). MPOB Information Series. Malaysia: Malaysian Palm Oil Board.

Tchobanoglous, G., Burton, F.L. and Stensel, H.D., 2004. Wastewater engineering, treatment and reuse. $4^{\text {th }}$ edn, New York: McGraw-Hill.

Tchobanoglous, G., Theisen, H. and Vigil, S., 1993. Integrated solid waste management. International edn, New York: McGraw-Hill.

Thanh, N.C., Muttamara, S. and Lohani, B.N., 1980. Palm oil wastewater treatment study in Malaysia and Thailand, Final Report No.114, Canada: International Development Research Centre.

Tin, J., 2010. POME treatment with bioflow effluent polishing plant: design and field experiences. Seminar \& Workshop on Palm Oil Mill Effluent Tertiary Treatment Technologies $\left(\mathrm{POMET}^{3}\right.$ ), Kota Kinabalu, Sabah, Malaysia.

Ugoji, E.O., 1997. Anaerobic digestion of palm oil mill effluent and its utilization as fertilizer for environmental protection. Renew. Energy 10, 291-294.

Whiting, D.A.M., 1983. Sterilisation station design / operation, Proceedings of Regional Workshop on Palm Oil Mill Technology and Effluent Treatment, 7-16. (in Malaysia)

Wong, K. K., 1980. Application of ponding systems in the treatment of palm oil mill and rubber mill effluents. Pertanika. 3(2), 133-141.

Wu, T. Y., Mohammad, A. W., Md. Jahim, J. and Anuar, N., 2010. Pollution control technologies for the treatment of palm oil mill effluent (POME) through end-of-pipe processes. Journal of Environmental Management. 91, 1467-1490. 
Wu, T.Y., Mohammad, A.W., Md. Jahim, J. and Anuar, N., 2009. A holistic approach to managing palm oil mill effluent (POME): biotechnological advances in the sustainable reuse of POME. Biotechnology Advances. 27, 40-52.

Yacob, S., Hassan, M.A., Shirai, Y., Wakisaka, M. and Subash, S., 2006a. Baseline study of methane emission from anaerobic ponds of palm oil mill effluent treatment. Science of the Total Environment. 366(1), 187-196.

Yacob, S., Shirai, Y., Hassan, M. A., Wakisaka, M. and Subash, S., 2006b. Start-up operation of semi-commercial closed anaerobic digester for palm oil mill effluent treatment. Process Biochemistry. 41, 962-964.

Zahrim, A. Y., Rachel, F. M., Menaka, S., Su, S. Y., Melvin, F. and Chan, E. S., 2009. Decolourisation of anaerobic palm oil mill effluent via activated sludge-granular activated carbon. World Applied Sciences Journal 5 (Special Issue for Environment), 126-129.

Zakaria, Z. Z., Hamdan, A. B. and Khalid, H., 1995. Land application of palm oil mill effluents guidelines and effects on soil, water and crop, Proceedings of Workshop on Environmental Quality Management in the Plantations, (in Malaysia), 46-54.

Zakaria, Z.Z., Haron, K. and Murdi, A.A., 2000. Current Status on Land Application of POME in the Oil Palm Industry - A Survey. PORIM Occasional Paper. No. 42. Malaysia: Palm Oil Research Institute of Malaysia, Ministry of Primary Industries. 
Click here to download Figure: Figure.doc

\section{List of Figures}

Fig. 1 - An overview of the Malaysian palm oil industry in year 2011. A - the number of palm oil processing mills in operation; B the fresh fruit bunches processed by mills (tonnes); $\mathrm{C}$ - the estimated POME production (tonnes); D - sterilizer condensate (tonnes); E - clarification wastewater (tonnes); F - hydrocyclone wastewater (tonnes).

Fig. 2 - Typical palm oil milling processes in addition to the sources of water pollution and by-products generation from the processing of one tonne of FFB. 


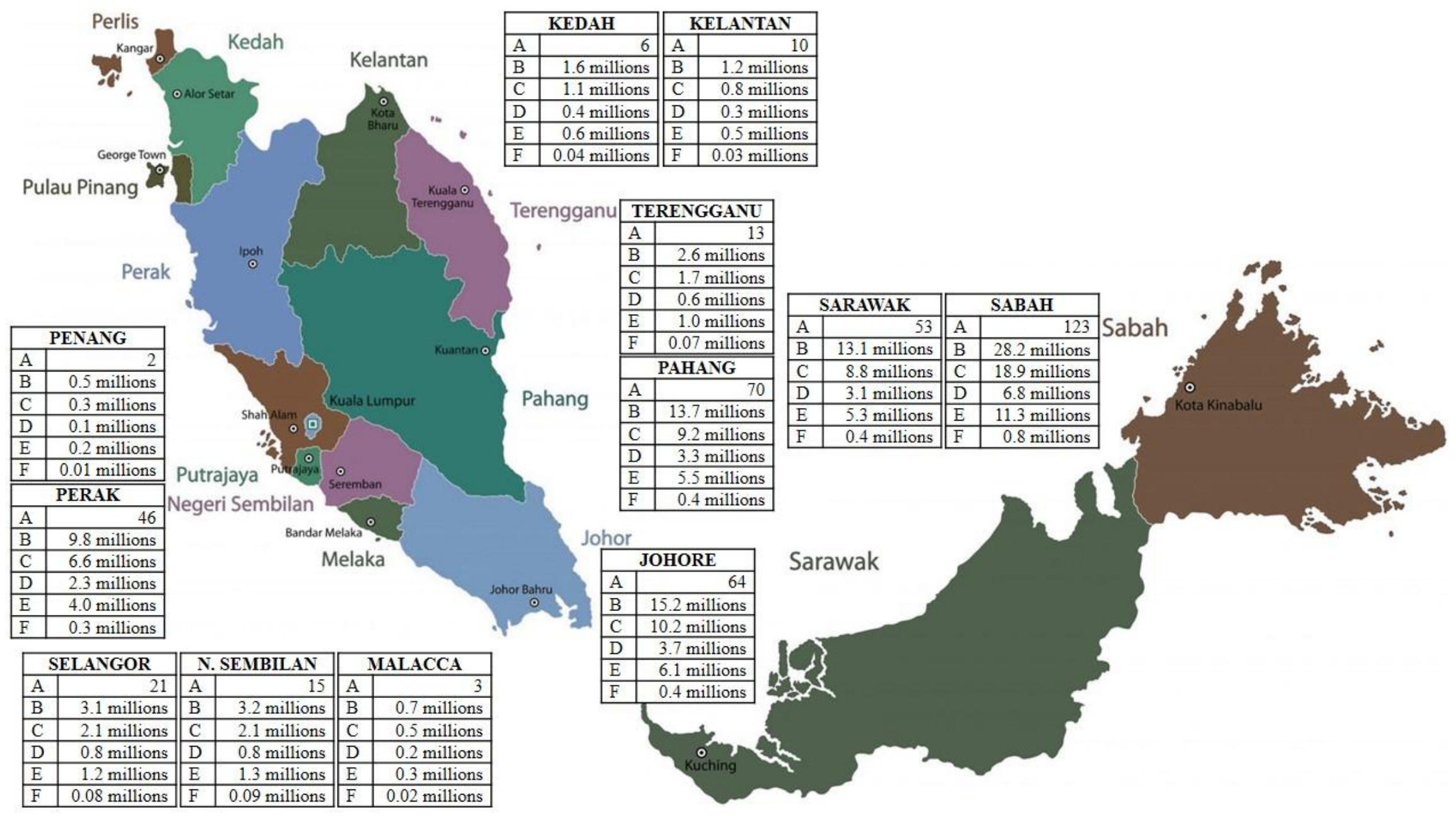

Fig. 1 - An overview of the Malaysian palm oil industry in year 2011. A - the number of palm oil processing mills in operation; B -

the fresh fruit bunches processed by mills (tonnes); $\mathrm{C}$ - the estimated POME production (tonnes); D - sterilizer condensate (tonnes); E

- clarification wastewater (tonnes); F - hydrocyclone wastewater (tonnes). 


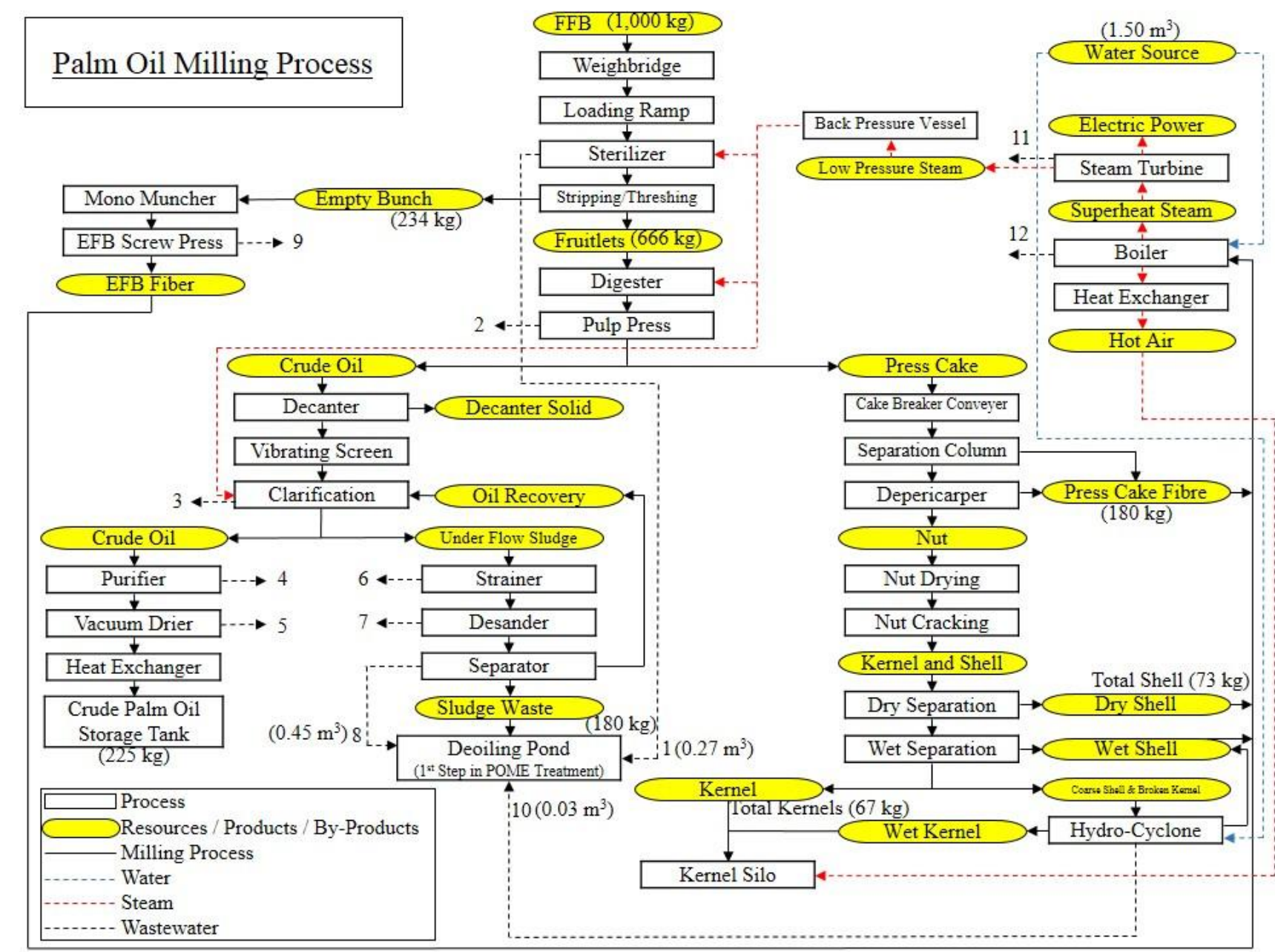

Fig. 2 - Typical palm oil milling processes in addition to the sources of water pollution and by-products generation from the processing of one tonne of FFB. 


\section{List of Tables}

Table 1 - Characteristics of different sources of wastewater combining to produce the POME.

Table 2 - Parameter limits for watercourse discharge.

Table 3 - Advantages and disadvantages of various types of land application of POME.

Table 4 - Summary of technologies / systems in treatability studies for POME tertiary treatment / polishing.

Table 5 - Summary of full scale technologies / systems for POME tertiary treatment / polishing. 
Table 1 - Characteristics of different sources of wastewater combining to produce the POME.

\begin{tabular}{lccc}
\hline \multicolumn{1}{c}{ Parameter } & Sterilizer Condensate & Clarification & Hydrocyclone \\
& & Wastewater & Wastewater \\
\hline $\mathrm{pH}$ & 5.0 & 4.5 & $-{ }^{\mathrm{b}}$ \\
Oil and Grease & 4,000 & 7,000 & 300 \\
Biochemical Oxygen Demand (BOD) & & 5,000 \\
Chemical Oxygen Demand (COD) & 23,000 & 29,000 & 15,000 \\
Suspended Solids & 47,000 & 64,000 & 7,000 \\
Dissolved Solids & 5,000 & 23,000 & 100 \\
Total Nitrogen & 34,000 & 22,000 & 100 \\
Ammoniacal-Nitrogen & 600 & 1,200 & $-{ }^{\mathrm{b}}$
\end{tabular}

All units in $\mathrm{mg} \mathrm{L}^{-1}$ except $\mathrm{pH}$.

${ }^{\mathrm{a}}$ Sample incubated for 3 days at $30^{\circ} \mathrm{C}$.

${ }^{\mathrm{b}}$ No values were reported for the parameter. 
Table 2 - Parameter limits for watercourse discharge.

Limits According to Periods of Discharge

\begin{tabular}{|c|c|c|c|c|c|c|}
\hline & & & & & & \\
\hline & $\begin{array}{c}\text { 1-7-1978- 30- } \\
6-1979\end{array}$ & $\begin{array}{c}\text { 1-7-1979-30- } \\
6-1980\end{array}$ & $\begin{array}{c}\text { 1-7-1980-30- } \\
6-1981\end{array}$ & $\begin{array}{c}\text { 1-7-1981-30- } \\
6-1982\end{array}$ & $\begin{array}{c}1-7-1982-31- \\
12-1983\end{array}$ & $\begin{array}{c}1-1-1984 \text { and } \\
\text { thereafter }\end{array}$ \\
\hline $\begin{array}{l}\text { Biochemical Oxygen Demand } \\
\text { (BOD) } 3 \text { days, } 30^{\circ} \mathrm{C} ; \mathrm{mg} \mathrm{L}^{-1}\end{array}$ & 5,000 & 2,000 & 1,000 & 500 & 250 & 100 \\
\hline $\begin{array}{l}\text { Chemical Oxygen Demand } \\
\text { (COD); } \mathrm{mg} \mathrm{L}^{-1}\end{array}$ & 10,000 & 4,000 & 2,000 & 1,000 & $-{ }^{b}$ & $-{ }^{b}$ \\
\hline Total Solids; mg L ${ }^{-1}$ & 4,000 & 2,500 & 2,000 & 1,500 & $-{ }^{b}$ & $-b$ \\
\hline Suspended Solids; mg L ${ }^{-1}$ & 1,200 & 800 & 600 & 400 & 400 & 400 \\
\hline Oil and Grease; $\mathrm{mg} \mathrm{L}^{-1}$ & 150 & 100 & 75 & 50 & 50 & 50 \\
\hline Ammoniacal-Nitrogen; $\mathrm{mg} \mathrm{L}^{-1}$ & 25 & 15 & 15 & 10 & $150^{\mathrm{a}}$ & $150^{\mathrm{a}}$ \\
\hline Total Nitrogen; mg L ${ }^{-1}$ & 200 & 100 & 75 & 50 & $300^{\mathrm{a}}$ & $200^{\mathrm{a}}$ \\
\hline $\mathrm{pH}$ & $5.0-9.0$ & $5.0-9.0$ & $5.0-9.0$ & $5.0-9.0$ & $5.0-9.0$ & $5.0-9.0$ \\
\hline Temperature ${ }^{\circ} \mathrm{C}$ & 45 & 45 & 45 & 45 & 45 & 45 \\
\hline
\end{tabular}

${ }^{a}$ Value of filtered sample.

${ }^{b}$ No values were reported for the parameter. 
Table 3- Advantages and disadvantages of various types of land application of POME.

\begin{tabular}{|c|c|c|}
\hline Types of Land Application & Advantages & Disadvantages \\
\hline \multirow[t]{3}{*}{ Sprinkler/pipe irrigation system } & Can reach higher planes and undulating area & $\begin{array}{l}\text { It often requires exceedingly long sections of } \\
\text { drip line }\end{array}$ \\
\hline & High energy, capital and maintenance costs & $\begin{array}{l}\text { Large areas may require the installation of a } \\
\text { water pump or additional piping to maintain } \\
\text { enough pressure throughout the drip line system }\end{array}$ \\
\hline & $\begin{array}{l}\text { Suitable for large expanse of land } \\
\text { Suitable to all types of soil except heavy clay } \\
\text { Elimination of the channels for conveyance, } \\
\text { therefore no conveyance loss }\end{array}$ & \\
\hline \multirow[t]{3}{*}{ Furrow/gravity flow system } & $\begin{array}{l}\text { Flow rate is dependent on the size of furrow and } \\
\text { are typically dictated by siphons or bank cuts }\end{array}$ & $\begin{array}{l}\text { The efficiency of furrow irrigation is generally } \\
<65 \%\end{array}$ \\
\hline & $\begin{array}{l}\text { Most suited to clay soils where the potential for } \\
\text { leaching is far less }\end{array}$ & $\begin{array}{l}\text { It has a higher risk of human exposure and } \\
\text { labour requirement }\end{array}$ \\
\hline & Low energy use & It cannot be used on steep land \\
\hline
\end{tabular}




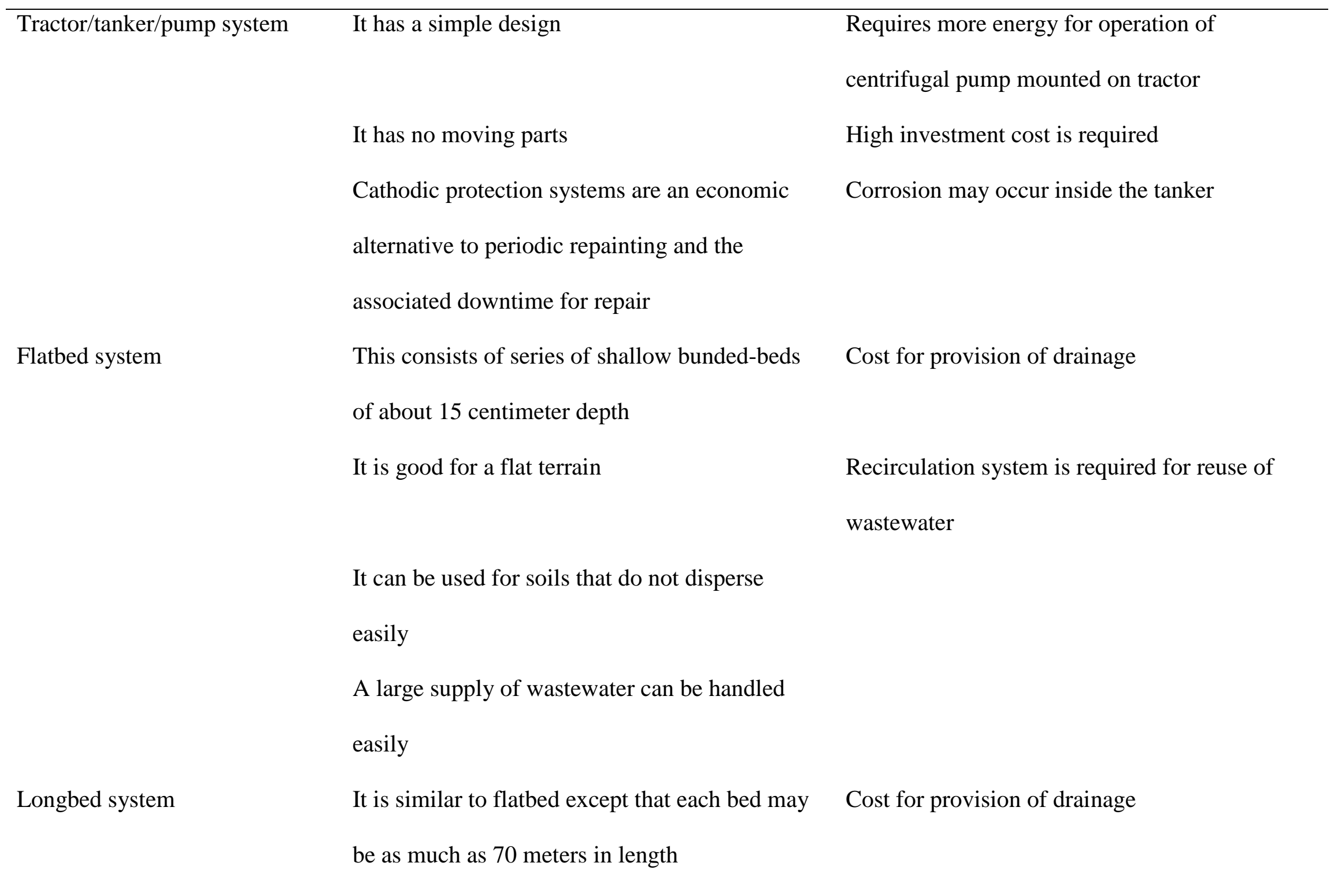


wastewater

It can be used for soils that do not disperse

easily 
Table 4 - Summary of technologies / systems in treatability studies for POME tertiary treatment / polishing.

\begin{tabular}{|c|c|c|c|c|c|}
\hline $\begin{array}{c}\text { Technologies / } \\
\text { Systems }\end{array}$ & Description & Removal Efficiencies & $\begin{array}{c}\text { Organic } \\
\text { Loading Rates }\end{array}$ & $\begin{array}{c}\text { Hydraulic } \\
\text { Retention Times }\end{array}$ & References \\
\hline Membrane & Pre-treatment - chemical & $\mathrm{AN} 99 \% ; \mathrm{BOD}_{3} 99 \%$ & N/A & $\mathrm{N} / \mathrm{A}$ & Ahmad et al., 2003; \\
\hline Filtration & coagulation (Envifloc 40L, & COD 99\%; Colour & & & Ahmad et al., 2006 \\
\hline \multirow[t]{6}{*}{ Processes } & $0.05 \mathrm{v} / \mathrm{v})$, flocculation & 100\%; Odour 100\%; & & & \\
\hline & (Envifloc $20 \mathrm{~S}, 0.015 \mathrm{v} / \mathrm{v})$ & OG 100\%; Turbidity & & & \\
\hline & sedimentation, and adsorption; & $100 \%$; Water recovery & & & \\
\hline & followed by membrane & $78 \%$. & & & \\
\hline & processes - ultrafiltration (UF) & & & & \\
\hline & and reverse osmosis (RO) & & & & \\
\hline Membrane & Ultrafiltration membrane & $\mathrm{AN} 62 \%$; $\mathrm{BOD}_{5}$ 97\%; & N/A & N/A & Nik Sulaiman and \\
\hline Filtration & process with hollow fibre & COD 98\%; SS 98\%; & & & Chea, 2004 \\
\hline \multirow[t]{2}{*}{ Processes } & membrane configuration; made & TKN 54\%; Turbidity & & & \\
\hline & by polyethersulphone material & $80 \%$. & & & \\
\hline Advanced & Technology to produce & COD 7-61\%; Colour & $\mathrm{N} / \mathrm{A}$ & $\mathrm{N} / \mathrm{A}$ & Abdullah, 2008 \\
\hline
\end{tabular}




\begin{tabular}{|c|c|c|c|c|c|}
\hline Oxidation & Hydroxyl radicals (HO*) - & $7-61 \%$. & & & \\
\hline $\begin{array}{l}\text { Processes } \\
\text { (AOPs) }\end{array}$ & $\begin{array}{l}\text { Hydrogen Peroxide/UV } \\
\left(\mathrm{H}_{2} \mathrm{O}_{2} / \mathrm{UV}\right)\end{array}$ & & & & \\
\hline Advanced & Technology to produce & Ambient Fenton - & N/A & $\mathrm{N} / \mathrm{A}$ & Aris et al., 2008 \\
\hline Oxidation & Hydroxyl radicals $\left(\mathrm{HO}^{*}\right)-$ & COD 75\%; Colour & & & \\
\hline Processes & Fenton oxidation process & $92 \%$. & & & \\
\hline \multirow[t]{4}{*}{ (AOPs) } & (1) Ambient Fenton - inside & Solar Fenton - & & & \\
\hline & laboratory under ambient light & COD 82\%; Colour & & & \\
\hline & (2) Solar Fenton - open space & $95 \%$. & & & \\
\hline & directly under sunlight & & & & \\
\hline Hybrid & Phase 1: anaerobic - activated & COD 94\%; SS 98\%; & $1.77-1.87 \mathrm{~kg}$ & $22 \mathrm{hr}$ & Ahmad et al., 2009 \\
\hline Membrane & sludge process; phase 2 : anoxic & TN 83\%; TOC 96\%; & $\operatorname{COD~m} \mathrm{m}^{-3} \mathrm{~d}^{-1}$ & & \\
\hline Bioreactor & - activated sludge process; & TP $64 \%$. & & & \\
\hline \multirow[t]{2}{*}{ System } & phase 3: aerobic (submerged- & & & & \\
\hline & membrane). & & & & \\
\hline Sequencing & 96 hr SBR operation (Fill 5 & COD 27-39\%; Colour & $\mathrm{N} / \mathrm{A}$ & $96 \mathrm{hr}$ & Zahrim et al., 2009 \\
\hline
\end{tabular}




Batch Reactor min, React 95 hr, Settle $15 \quad$ 0\%-14\%.

(SBR), with $\min$, Decant $10 \mathrm{~min}$ ).

Suspended

Activated

Sludge (SAS)

\begin{tabular}{|c|c|c|c|c|c|}
\hline Sequencing & 96 hr SBR operation (Fill 5 & COD 59-70\%; Colour & N/A & $96 \mathrm{hr}$ & Zahrim et al., 2009 \\
\hline $\begin{array}{l}\text { Batch Reactor } \\
\text { (SBR), with }\end{array}$ & $\begin{array}{l}\text { min, React } 95 \text { hr, Settle } 15 \\
\text { min, Decant } 10 \mathrm{~min}) .\end{array}$ & $28-41 \%$ & & & \\
\hline \multicolumn{6}{|l|}{ Activated } \\
\hline \multicolumn{6}{|l|}{ Sludge - } \\
\hline \multicolumn{6}{|l|}{ Granular } \\
\hline \multicolumn{6}{|l|}{ Activated } \\
\hline \multicolumn{6}{|l|}{ Carbon } \\
\hline \multicolumn{6}{|l|}{ (ASGAC) } \\
\hline Sequencing & 22 hr SBR operation (Fill, & $\mathrm{BOD}_{3} 97-98 \% ; \mathrm{COD}$ & $1.8-4.2 \mathrm{~kg}$ & $20 \mathrm{hr}$ & Chan et al., 2010 \\
\hline Batch Reactor & React $20 \mathrm{hr}$, Settle $2 \mathrm{hr}$, & 95-96\%; SS 98-99\%; & $\operatorname{COD~m^{-3}} \mathrm{d}^{-1}$ & & \\
\hline
\end{tabular}




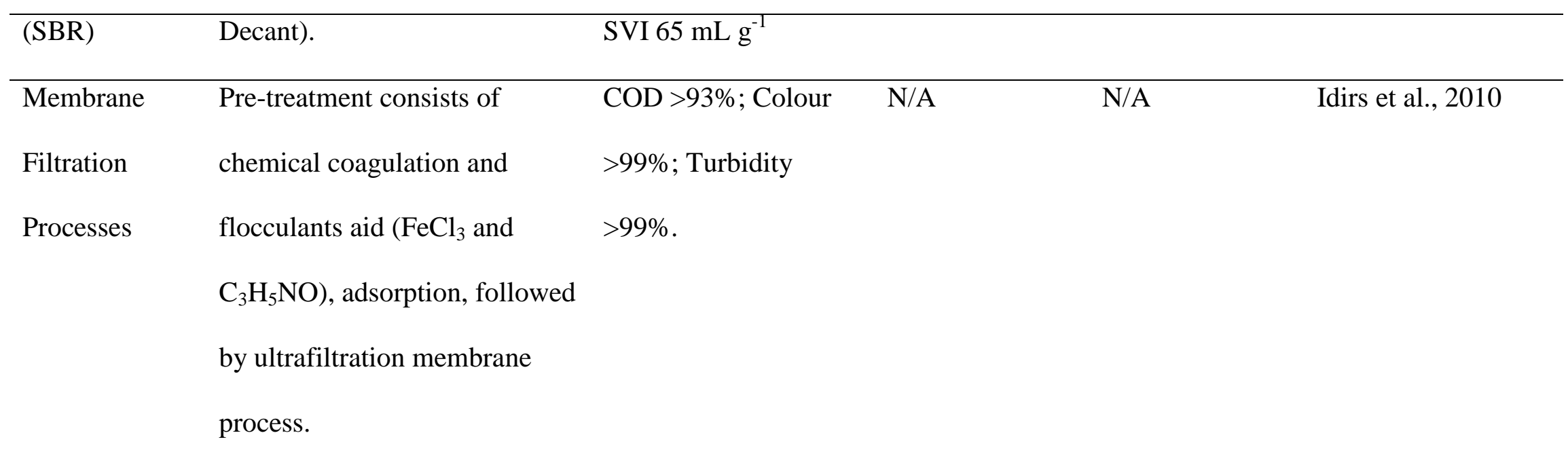

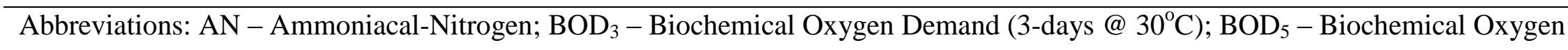

Demand (5-days @ 20 C); COD - Chemical Oxygen Demand; OG - Oil and Grease; SS - Suspended Solids; SVI - Sludge Volume

Index; TKN - Total Kjeldahl Nitrogen; TN - Total Nitrogen; TOC - Total Organic Carbon; TP - Total Phosphorus. 
Table 5 - Summary of full scale technologies / systems for POME tertiary treatment / polishing.

\begin{tabular}{|c|c|c|c|}
\hline Technologies $^{\mathrm{a}}$ & Description & Removal Efficiency & References \\
\hline Membrane Bioreactor & Phase 1 - Anoxic sector (activated sludge process); & $\mathrm{BOD}_{3}$ 99\%; COD 98\%; & Sulong et al., 2007 \\
\hline Technology (MBR) & $\begin{array}{l}\text { phase } 2 \text { - aerobic sector (activated sludge process); } \\
\text { and phase } 3 \text { - ultrafiltration membrane process. }\end{array}$ & SS $99 \%$. & \\
\hline Biological- & Phase 1 - biological treatment (aerobic suspended & Ammonia, $\mathrm{BOD}_{3}$ & Sulong and Abdul \\
\hline Physicochemical & growth processes - activated sludge process); phase 2 & colour, and residual SS & Wahab, 2008 \\
\hline Treatment Processes & $\begin{array}{l}\text { - chemical treatment (chemical coagulation - } \\
\text { flocculation); and phase } 3 \text { - physical treatment } \\
\text { (screening and sedimentation). }\end{array}$ & removal. & \\
\hline $\begin{array}{l}\text { Sequencing Batch Reactor } \\
\text { (SBR) - Constructed }\end{array}$ & $\begin{array}{l}\text { Phase } 1 \text { - sequencing batch reactor process for } \\
\text { extended aeration; and phase } 2 \text { - constructed wetland }\end{array}$ & $\mathrm{BOD}_{3}<20 \mathrm{mg} \mathrm{L}^{-1}$ & Chong and Tan, 2010 \\
\hline Wetland System & $\begin{array}{l}\text { system with aquatic processing units (Cat Tails } \\
\text { plant). }\end{array}$ & & \\
\hline $\begin{array}{l}\text { Suspended Packing in } \\
\text { Activated Sludge Aeration }\end{array}$ & $\begin{array}{l}\text { Phase } 1 \text { - clarifier and hence gradual acclimatization } \\
\text { of ultra-aerobic microbes in completely mixed }\end{array}$ & $\mathrm{BOD}_{3}<20 \mathrm{mg} \mathrm{L}^{-1}$ & Tin, 2010 \\
\hline
\end{tabular}




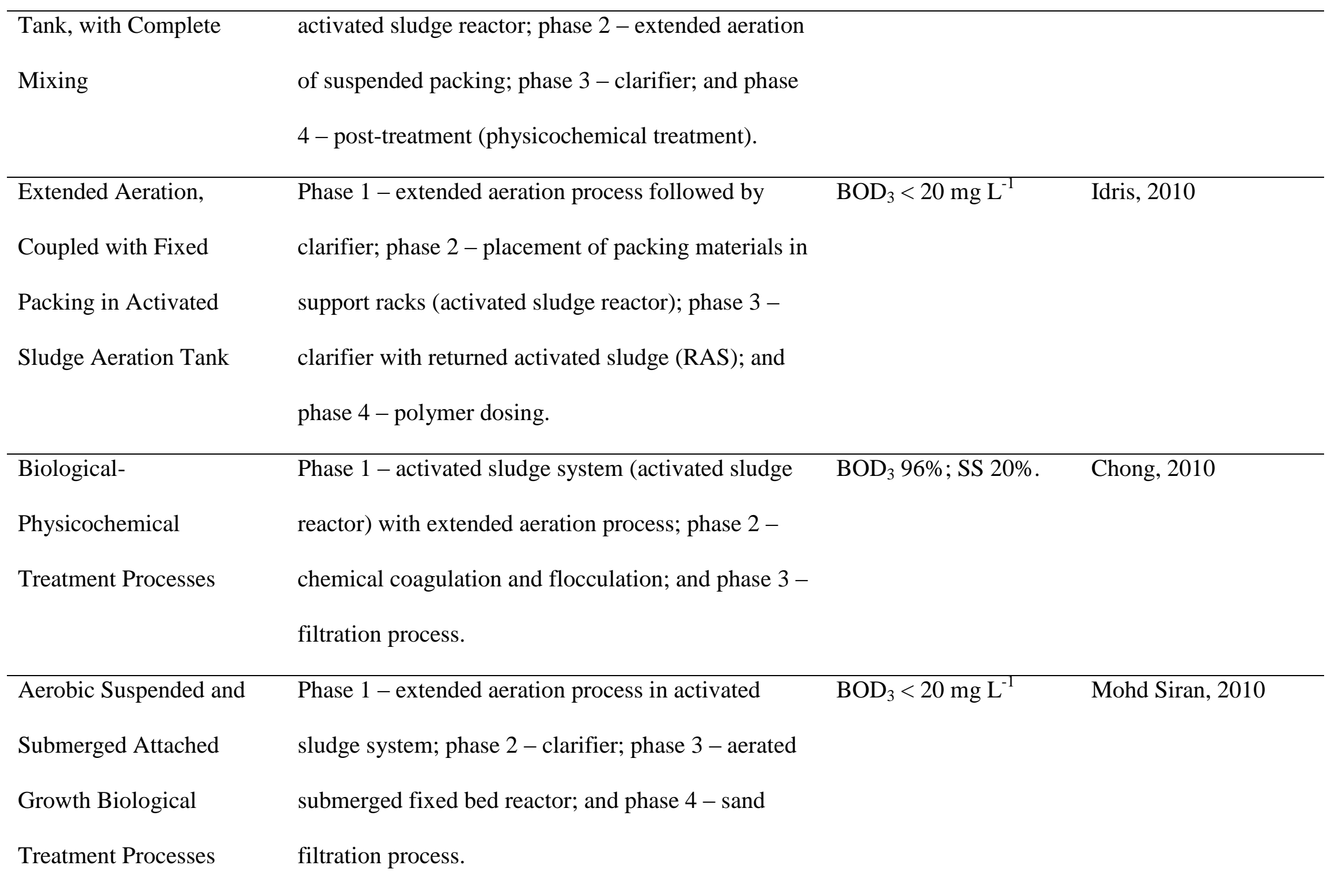




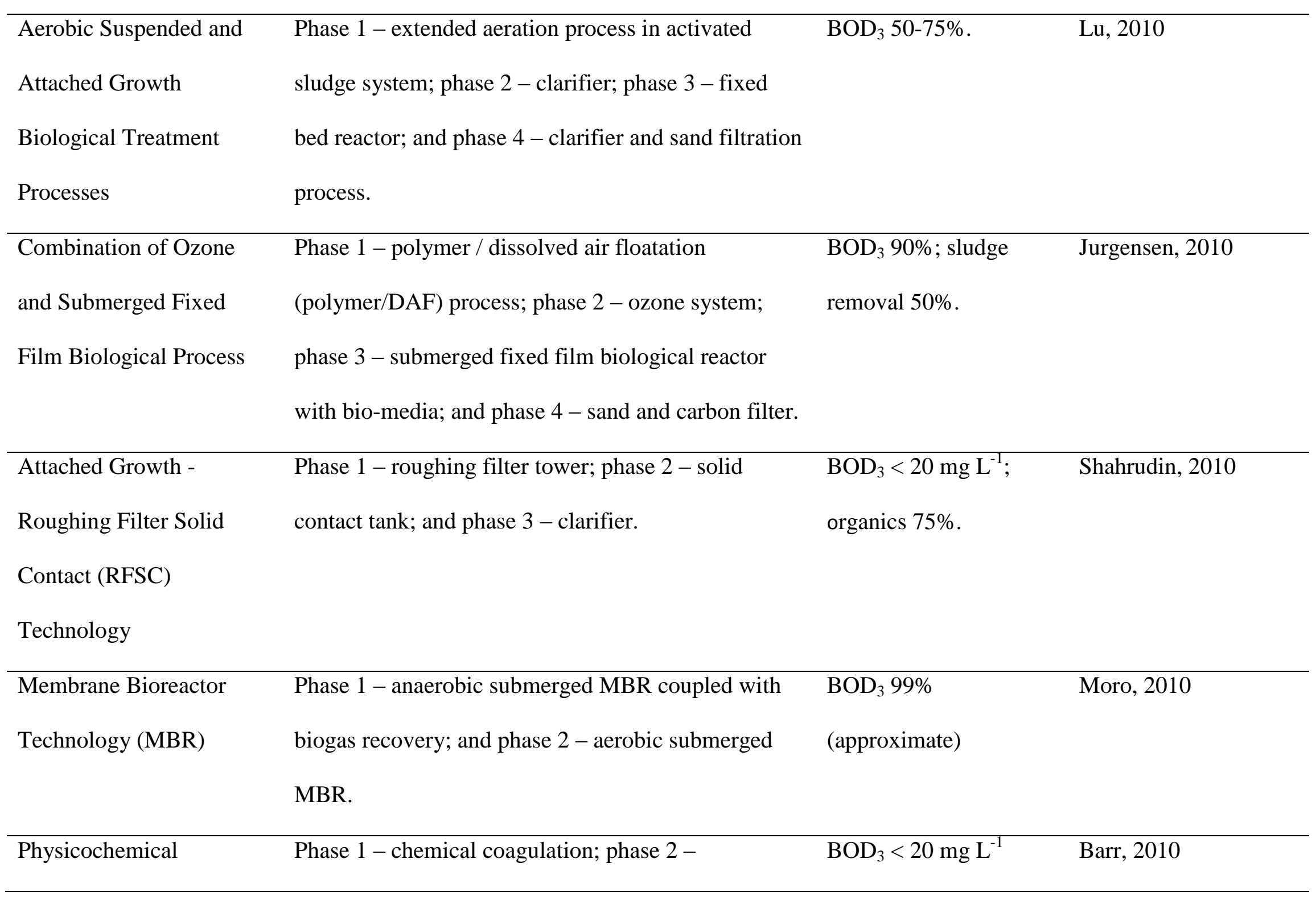




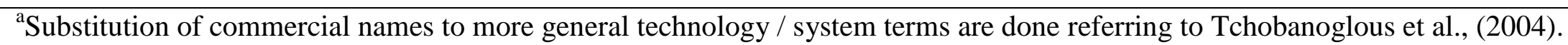

Abbreviations: $\mathrm{BOD}_{3}$ - Biochemical Oxygen Demand (3-days @ 30 $\mathrm{C}$ ); COD - Chemical Oxygen Demand; SS - Suspended Solids. 